[Review Paper]

\title{
Hydrodesulfurization of Dibenzothiophene Catalyzed by Supported Metal Carbonyl Complexes
}

\author{
Atsushi IshIHARA*, Weihua QIAN, and Toshiaki KABE \\ Dept. of Chemical Engineering, Faculty of Technology, Tokyo University of Agriculture and Technology, \\ Nakacho, Koganei, Tokyo 184-8588, JAPAN
}

(Received September 22, 2000)

\begin{abstract}
Hydrodesulfurization (HDS) of dibenzothiophene (DBT) catalyzed by supported anionic molybdenum and ruthenium carbonyl complexes is described, specifically the catalytic activity and the product selectivity. A $\mathrm{Mo}(\mathrm{CO})_{6}-\mathrm{NEt}_{3}-\mathrm{EtSH} / \mathrm{Al}_{2} \mathrm{O}_{3}$ system activated by $\mathrm{H}_{2}$ or $\mathrm{H}_{2} \mathrm{~S}$ shows the highest catalytic activity among catalysts derived from supported-metal carbonyls and conventional molybdena-alumina. Investigation of the effects of supports found the yields of $\mathrm{HDS}$ products decreased in the order, $\mathrm{SiO}_{2}-\mathrm{Al}_{2} \mathrm{O}_{3}>\mathrm{Al}_{2} \mathrm{O}_{3}>\mathrm{TiO}_{2}=\mathrm{Active}$ carbon $>$ $\mathrm{SiO}_{2}>\mathrm{NaY}$ zeolite $=\mathrm{HZSM}-5>\mathrm{HY}$ zeolite.

The effects of addition of alkali metal hydroxide on the catalytic activity and product selectivity of sulfided alumina-supported ruthenium carbonyls in HDS of DBT were described. Addition of an alkali metal hydroxide to catalysts derived from alumina-supported $\mathrm{Ru}_{3}(\mathrm{CO})_{12}$ remarkably increased the conversion of DBT. The $\mathrm{Ru}_{3}(\mathrm{CO})_{12}$ must be supported on alumina so that the reaction with the alkali metal hydroxide will form an anionic ruthenium hydride complex $\left[\mathrm{HRu}_{3}(\mathrm{CO})_{11}\right]^{-}$, which is essential to obtain the high catalytic activity. Cesium was the most effective of the alkali metals. The conversion of DBT reaches the maximum at $\mathrm{Cs} / \mathrm{Ru}=2$. Further addition of cesium decreased the activity. Biphenyl was produced selectively in this system.

The involvement of cesium was elucidated by tracing the behavior of ${ }^{35} \mathrm{~S}$ on the alumina-supported ruthenium carbonyls-cesium hydroxide systems in HDS of ${ }^{35}$ S]DBT. The amount of labile sulfur was estimated from the amount of ${ }^{35} \mathrm{~S}$ accommodated on the catalyst. The rate constant of $\left[{ }^{35} \mathrm{~S}_{\mathrm{H}} \mathrm{S}\right.$ release was estimated from the first order plot of the decreasing radioactivity of product $\left[{ }^{35} \mathrm{~S}_{\mathrm{H}} \mathrm{H}_{2} \mathrm{~S}\right.$. The results obtained indicated that the dispersion of ruthenium species was significantly high. Cesium probably promotes the C-S bond scission of DBT and increases the activity by stabilizing the $\mathrm{Ru}-\mathrm{S}$ bonds of ruthenium sulfide.
\end{abstract}

\section{Introduction}

Recently, air pollution caused by diesel exhaust gas has increased in big city areas and much attention has been focused on the development of methods of clean fuel production such as deep desulfurization of light gas oil ${ }^{1,2)}$. Alumina-supported molybdenum-based catalysts have been widely used as the catalysts of petroleum hydrotreatment for a long time, but novel catalysts with high catalytic activity are required to achieve clean fuel production. Conventional molybdena-alumina catalysts can be prepared using ammonium heptamolybdate, or supported metal complexes can be used. Metal sulfide complexes have been used for preparing supported and unsupported hydrotreating catalysts ${ }^{3) \sim 6 \text { ) }}$. Supported metal carbonyl complexes are active in several catalytic reactions ${ }^{7)} \sim 11$ ), such as hydrogenation of carbon monoxide ${ }^{12) \sim 14)}$, metathesis of olefins ${ }^{15), 16)}$, etc. The reactivities of alumina-supported molybdenum carbonyls are well known ${ }^{17), 18)}$. However, the reactivities in the hydrodesulfurization (HDS) of thiophenes are unclear, especially in a pressurized flow system.

\footnotetext{
* To whom correspondence should be addressed.
}

Thiophene HDS has been investigated over catalysts derived from supported-Mo(CO $)_{6}$ under atmospheric pressure $^{19), 20)}$, using zeolite-supported catalysts ${ }^{21)-25)}$ and cluster complexes which may be regarded as models of heterogeneous active phases ${ }^{26) \sim 28)}$. Cobalt carbonyls such as $\mathrm{Co}_{2}(\mathrm{CO})_{8}$ or $\mathrm{Co}(\mathrm{CO})_{3} \mathrm{NO}$ were also used with $\mathrm{Mo}(\mathrm{CO})_{6}$ to prepare Co-Mo catalysts ${ }^{20), 29), 30)}$. However, the HDS reactions were often performed in a batch system or under atmospheric conditions, and the differences in the reaction conditions could cause discrepancies. Further, the HDS reactivity of catalysts derived from supported metal carbonyls in pressurized flow systems is not yet well-known.

Dibenzothiophene (DBT) is less reactive than thiophene and benzothiophene ${ }^{1), 2}$. Further, DBT is a key compound in the deep HDS of light gas oil ${ }^{1)}$. However, little information is available on the HDS of DBT catalyzed by supported metal carbonyls ${ }^{31), 32)}$.

This review discusses the HDS of DBT catalyzed by supported anionic molybdenum and ruthenium carbonyl complexes derived from $\mathrm{Mo}(\mathrm{CO})_{6}$ and $\mathrm{Ru}_{3}(\mathrm{CO})_{12}$, specifically the catalytic activity and the product selectivity. Anionic metal carbonyls are supported on alumina or silica-alumina. The vaporization 


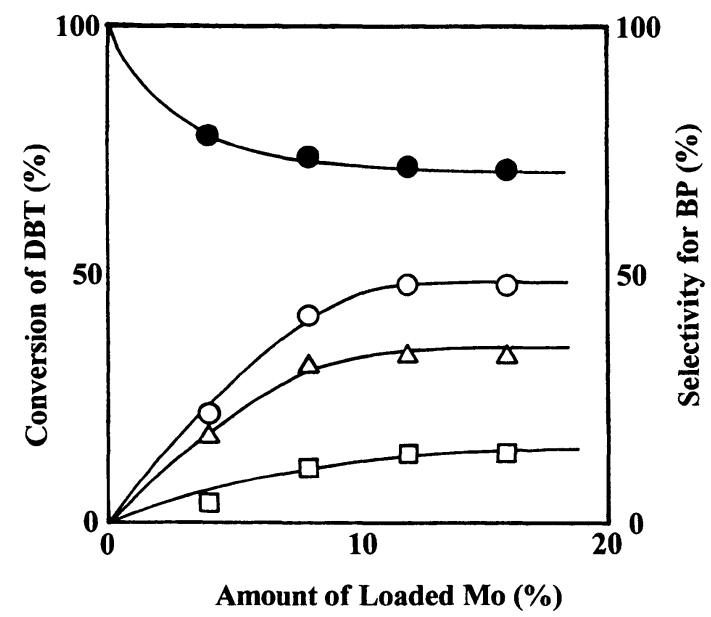

Total conversion of DBT, $\triangle$ Conversion of DBT into BP, $\square$ Conversion of DBT into CHB, Selectivity for BP.

Fig. 1 Effect of the Amount of Loaded Mo on the Conversion of DBT and the Selectivity for BP

of the metal species during activation processes can be inhibited by the use of these salts in heterogeneous catalytic reactions ${ }^{12)}$ 14), because the vapor pressure of these anionic salts is much smaller than that of neutral metal carbonyls. Further, the hydrotreatment of metal carbonyls with metal sulfur bonds will form metal sulfides. This review begins with the catalysts derived from $\mathrm{Mo}(\mathrm{CO})_{6}-\mathrm{NEt}_{3}-\mathrm{EtSH} / \mathrm{Al}_{2} \mathrm{O}_{3}$ systems, in which $\mathrm{Mo}(\mathrm{CO})_{6}$ reacts with triethylamine $\left(\mathrm{NEt}_{3}\right)$ and ethanethiol (EtSH) to form an anionic molybdenum carbonyl with metal-sulfur bonds ${ }^{33), 34)}$.

\section{Hydrodesulfurization of Dibenzothiophene Using Alumina-supported Molybdenum Carbonyls}

HDS of DBT on the catalysts derived from aluminasupported molybdenum carbonyls was performed in a pressurized fixed-bed flow reactor under the following conditions: temperature, $300^{\circ} \mathrm{C} ; 50 \mathrm{~kg} / \mathrm{cm}^{2} ; \mathrm{H}_{2}$ flow 18 $l / \mathrm{h}$; WHSV $16.5 \mathrm{~h}^{-1}$; initial concentration of DBT, 1.0 wt\%; solvent xylene; catalyst, $0.5 \mathrm{~g}$. Catalysts derived from alumina-supported molybdenum carbonyl complexes were active in the HDS of DBT for over $10 \mathrm{~h}$ and the products were biphenyl (BP), cyclohexylbenzene ( $\mathrm{CHB}$ ) and a trace amount of hexahydrodibenzothiophene.

$\mathrm{Mo}(\mathrm{CO})_{6}-\mathrm{NEt}_{3}-\mathrm{EtSH} / \mathrm{Al}_{2} \mathrm{O}_{3}$ was prepared as follows. Tetrahydrofuran (THF) solution of $\mathrm{Mo}(\mathrm{CO})_{6}$ was stirred under UV irradiation and reflux for $2 \mathrm{~h}$ to give $\mathrm{Mo}(\mathrm{CO})_{5} \mathrm{THF}^{35}$ ) which reacted with $\mathrm{NEt}_{3}$ and EtSH (Mo: $\mathrm{N}: \mathrm{S}=1: 2: 2$ ) at room temperature to give a dark brown solution. This solution showed IR absorptions at 1941 (vs) and $1871(\mathrm{~m}) \mathrm{cm}^{-1}$ which were attributed to the formation of $\left[\mathrm{NEt}_{3} \mathrm{H}\right]\left[\mathrm{Mo}_{2}(\mathrm{CO})_{10} \mathrm{SEt}\right]$

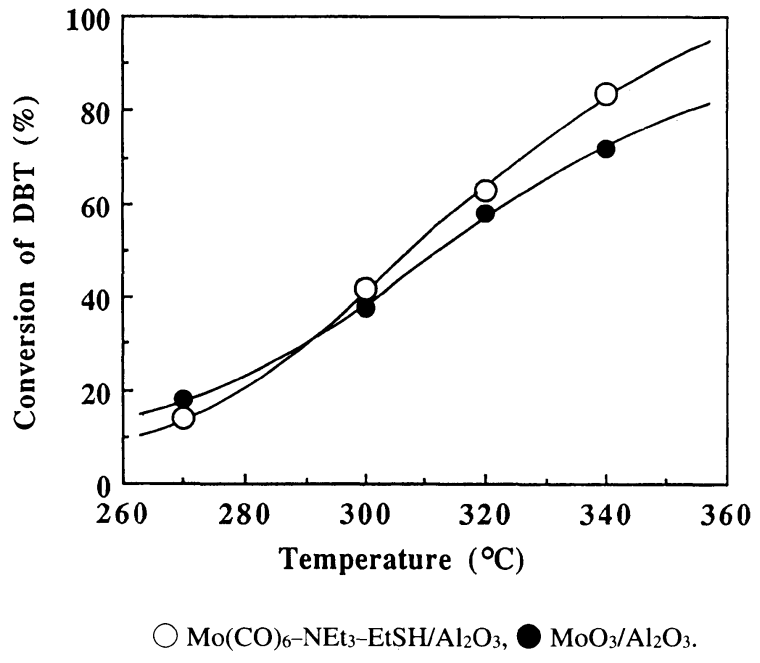

Fig. 2 Effect of Temperature on the Conversion of DBT

(vide infra) ${ }^{36)}$. $\quad \mathrm{Al}_{2} \mathrm{O}_{3}$ was added to the solution. The mixture was stirred for $2 \mathrm{~h}$, after which THF was removed in vacuo.

The most active catalysts were derived from the hydrogenolysis and presulfiding of $\mathrm{Mo}(\mathrm{CO})_{6}-\mathrm{NEt}_{3}-$ $\mathrm{EtSH} / \mathrm{Al}_{2} \mathrm{O}_{3}$ (Mo: $\left.\mathrm{N}: \mathrm{S}=1: 1: 1\right)$, which provided conversions of DBT up to $43 \%$. When two-fold amounts of $\mathrm{NEt}_{3}$ and $\mathrm{EtSH}$ were used in the preparation of the catalyst, the catalyst derived from hydrogenolysis showed $43 \%$ conversion of DBT, whereas the catalyst derived from presulfiding showed reduced conversion. The conversion of DBT depended on the amounts of $\mathrm{NEt}_{3}$ and EtSH added at the preparation of the catalyst. Figure 1 shows the effects of the amount of loaded Mo on the conversion of DBT and the selectivity for BP. The conversion of DBT increased with the amount of Mo loaded, reaching the maximum at $12 \mathrm{wt} \%$ of Mo loaded, and the conversion remained constant above $12 \mathrm{wt} \%$ of Mo. Similar results have been reported for $\mathrm{MoO}_{3} / \mathrm{Al}_{2} \mathrm{O}_{3}$ derived from ammonium heptamolybdate ${ }^{37)}$. Figure 2 shows the effects of temperature on the conversion of DBT over $\mathrm{Mo}(\mathrm{CO})_{6}-\mathrm{NEt}_{3}-\mathrm{EtSH} / \mathrm{Al}_{2} \mathrm{O}_{3}$ and $\mathrm{MoO}_{3} / \mathrm{Al}_{2} \mathrm{O}_{3}$ systems. The catalyst derived from $\mathrm{Mo}(\mathrm{CO})_{6}-\mathrm{NEt}_{3}-$ $\mathrm{EtSH} / \mathrm{Al}_{2} \mathrm{O}_{3}$ showed higher catalytic activity over $300^{\circ} \mathrm{C}$ than that from $\mathrm{MoO}_{3} / \mathrm{Al}_{2} \mathrm{O}_{3}$.

\section{Effects of Supports on Catalysts Prepared from Supported Anionic Molybdenum Carbonyls}

The use of alumina-supported anionic molybdenum carbonyls inhibited the sintering and sublimation of the molybdenum species and maintained the dispersion of molybdenum sulfide on the support ${ }^{34)}$. When a support with a larger surface area than that of alumina is used, higher dispersion of metal species could be 
Table 1 Hydrodesulfurization of Dibenzothiophene Catalyzed by Supported $\left[\mathrm{NEt}_{4}\right]\left[\mathrm{Mo}(\mathrm{CO})_{5}\left(\mathrm{CH}_{3} \mathrm{COO}\right)\right] \mathrm{Catalysts}^{\mathrm{a})}$

\begin{tabular}{|c|c|c|c|c|c|c|c|}
\hline Run & Support & $\begin{array}{c}\text { Conv. of }{ }^{\text {b) }} \\
\text { DBT } \\
{[\%]}\end{array}$ & $\begin{array}{c}\text { Conv. of } \\
\text { DBT to BP } \\
{[\%]}\end{array}$ & $\begin{array}{c}\text { Conv. of DBT } \\
\text { to CHB } \\
{[\%]}\end{array}$ & $\begin{array}{c}\text { Rate }^{\mathrm{c})} \\
\text { of HDS } \\
{[\mathrm{mol} / \mathrm{mol}-\mathrm{Mo} / \mathrm{h}]}\end{array}$ & $\begin{array}{c}\text { Mo } \\
\text { content } \\
{[w t \%]}\end{array}$ & $\begin{array}{c}\text { Surface area } \\
{\left[\mathrm{m}^{2} / \mathrm{g}\right]}\end{array}$ \\
\hline 1 & $\mathrm{SiO}_{2}-\mathrm{Al}_{2} \mathrm{O}_{3}$ & $85(58)$ & 26 & 32 & 0.71 & 7.0 & 560 \\
\hline 2 & $\mathrm{Al}_{2} \mathrm{O}_{3}$ & $35(35)$ & 23 & 12 & 0.48 & 6.2 & 260 \\
\hline 3 & $\mathrm{SiO}_{2}$ & $20(20)$ & 17 & 3 & 0.24 & 7.0 & 347 \\
\hline 4 & $\mathrm{TiO}_{2}$ & $31(31)$ & 18 & 13 & 0.60 & 4.4 & 71 \\
\hline 5 & $\mathrm{NaY}$ zeolite & $14(14)$ & 13 & 1 & 0.52 & 2.3 & 670 \\
\hline 6 & HY zeolite & $75(0)$ & 0 & 0 & - & - & 663 \\
\hline 7 & HZSM-5 & $14(14)$ & 7 & 7 & - & - & - \\
\hline 8 & Active carbon & $61(31)$ & 19 & 12 & - & - & $1200>$ \\
\hline
\end{tabular}

a) Reaction temp. $300^{\circ} \mathrm{C}$, Pressure $50 \mathrm{~kg} / \mathrm{cm}^{2}$, WHSV $16.5 \mathrm{~h}^{-1}$, Cat. $0.50 \mathrm{~g}, \mathrm{H}_{2} 18 \mathrm{l} / \mathrm{h}$; initial concentration of DBT $1.0 \mathrm{wt} \%$. Presulfided by $\mathrm{H}_{2} \mathrm{~S}$ in $\mathrm{H}_{2}$ at $350^{\circ} \mathrm{C}\left(\mathrm{H}_{2} \mathrm{~S} \mathrm{3 \%}\right)$. b) Yields of $\mathrm{BP}$ and $\mathrm{CHB}$, i.e., the sum of the conversions of DBT to BP and CHB are given in parentheses. c) Rate of HDS of DBT into BP and CHB. This value was calculated from the sum of the conversions of DBT to BP and CHB.

obtained to provide higher catalytic activity. This section describes the effects of supports on HDS of DBT catalyzed by supported metal carbonyl complexes ${ }^{34), 38), 39)}$. $\mathrm{SiO}_{2}-\mathrm{Al}_{2} \mathrm{O}_{3}, \mathrm{Al}_{2} \mathrm{O}_{3}, \mathrm{SiO}_{2}, \mathrm{TiO}_{2}, \mathrm{NaY}$ zeolite, HY zeolite, HZSM-5, and active carbon were used as the supports and the anionic carbonyl, [NEt 4 ] $\left[\mathrm{Mo}(\mathrm{CO})_{5}\left(\mathrm{OOCCH}_{3}\right)\right]\left(\mathrm{Et}=\mathrm{C}_{2} \mathrm{H}_{5}\right)^{40)}$, as a precursor for the HDS of DBT catalyzed by supported anionic molybdenum carbonyls.

The results are shown in Table 1. When silicaalumina was used as the support, the total conversion of DBT was $85 \%$ and the yield of BP and CHB was $58 \%$. The difference between the total conversion $(85 \%)$ and the yields of $\mathrm{BP}$ and $\mathrm{CHB}(58 \%)$ indicates the conversion of DBT by hydrocracking that does not yield BP or CHB.

When $\mathrm{Al}_{2} \mathrm{O}_{3}, \mathrm{SiO}_{2}, \mathrm{TiO}_{2}$, and $\mathrm{NaY}$ zeolite supports were used, the yields of $\mathrm{BP}$ and $\mathrm{CHB}$ decreased to 35 , 20,31 and $14 \%$, respectively. However, hydrocracking activity was not observed, as the selectivities for BP were $66,85,58$ and $93 \%$, respectively, and were higher than the selectivity of $\mathrm{SiO}_{2}-\mathrm{Al}_{2} \mathrm{O}_{3}$ assuming that the selectivity for BP will not change with temperature so much as the conversion of DBT. As shown in Table 1, the rates of HDS decreased in the order $\mathrm{TiO}_{2}>\mathrm{NaY}$ zeolite $>\mathrm{Al}_{2} \mathrm{O}_{3}>\mathrm{SiO}_{2}$. Although the amounts of molybdenum species loaded on $\mathrm{TiO}_{2}$ and $\mathrm{NaY}$ zeolite were less than those on the other supports, these supports provided higher rates of HDS per molybdenum atom. The results obtained from the use of HY zeolite were different. The total conversion of DBT was $75 \%$, close to that of $\mathrm{SiO}_{2}-\mathrm{Al}_{2} \mathrm{O}_{3}$. However, a large number of products with carbon numbers lower than 12 were formed by hydrocracking, with yields of a few percent each, and no HDS products such as BP and $\mathrm{CHB}$ were detected, indicating that the aromatic structure of DBT was significantly destroyed by acid sites on the catalyst. Using HZSM-5, the conversion of DBT was $14 \%$ and hydrocracking activity was not observed. Using active carbon, the total yield of BP

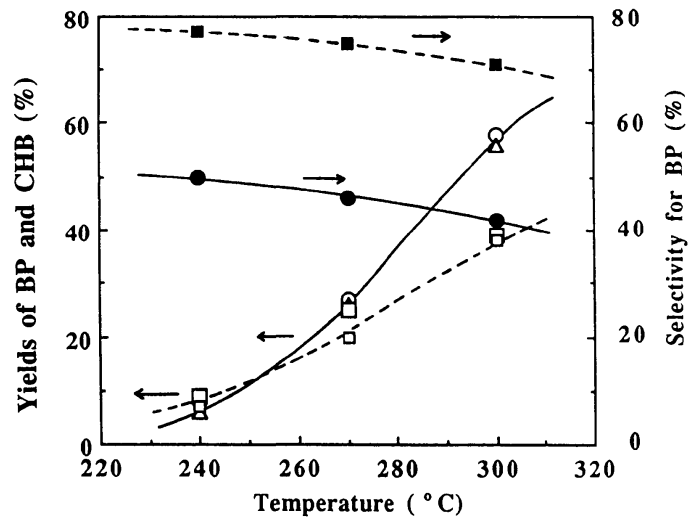

Yield of BP and $\mathrm{CHB}(\%)$

○ $\left[\mathrm{NEt}_{4}\right]\left[\mathrm{Mo}(\mathrm{CO})_{5}\left(\mathrm{CH}_{3} \mathrm{COOH}\right)\right] / \mathrm{SiO}_{2}-\mathrm{Al}_{2} \mathrm{O}_{3}, \square-\mathrm{MoO}_{3} /$

$\mathrm{SiO}_{2}-\mathrm{Al}_{2} \mathrm{O}_{3}, \triangle \mathrm{Mo}(\mathrm{CO})_{6}-2\left(\mathrm{EtSH}-\mathrm{NEt}_{3}\right) / \mathrm{SiO}_{2}-\mathrm{Al}_{2} \mathrm{O}_{3}$,

$\square \mathrm{MoO}_{3} / \mathrm{Al}_{2} \mathrm{O}_{3}$.

Selectivity for $\mathrm{BP}(\%)$

․ $\left[\mathrm{NEt}_{4}\right]\left[\mathrm{Mo}(\mathrm{CO})_{5}\left(\mathrm{CH}_{3} \mathrm{COOH}\right)\right] / \mathrm{SiO}_{2}-\mathrm{Al}_{2} \mathrm{O}_{3}$, ․․ $\mathrm{MoO}_{3} / \mathrm{Al}_{2} \mathrm{O}_{3}$.

Fig. 3 Effect of Temperature on the Yields of BP and CHB and the Selectivity for BP

and $\mathrm{CHB}$ was $31 \%$. In this case, hydrocracking activity was also not observed. The difference between the total conversion and HDS yields is probably due to the adsorption of DBT and products onto the support because the material balance was not complete within an HDS run of several hours.

To investigate the effect of temperature, the yields of $\mathrm{BP}$ and $\mathrm{CHB}$ were plotted against temperature in Fig. 3. Four types of catalysts derived from [NEt $\left[\mathrm{Mo}(\mathrm{CO})_{5}\left(\mathrm{OOCCH}_{3}\right)\right] / \mathrm{SiO}_{2}-\mathrm{Al}_{2} \mathrm{O}_{3}, \mathrm{Mo}(\mathrm{CO})_{6}-\mathrm{NEt}_{3}-\mathrm{EtSH} /$ $\mathrm{SiO}_{2}-\mathrm{Al}_{2} \mathrm{O}_{3}, \mathrm{MoO}_{3} / \mathrm{SiO}_{2}-\mathrm{Al}_{2} \mathrm{O}_{3}$, and $\mathrm{MoO}_{3} / \mathrm{Al}_{2} \mathrm{O}_{3}$ systems were used. The yields and apparent activation energies of the catalysts derived from [NEt 4 $\left[\mathrm{Mo}(\mathrm{CO})_{5}\left(\mathrm{OOCCH}_{3}\right)\right] / \mathrm{SiO}_{2}-\mathrm{Al}_{2} \mathrm{O}_{3}$ and $\mathrm{Mo}(\mathrm{CO})_{6}-\mathrm{NEt}_{3}-$ $\mathrm{EtSH} / \mathrm{SiO}_{2}-\mathrm{Al}_{2} \mathrm{O}_{3}$ systems were very similar. The yields and apparent activation energies of the catalysts derived from $\mathrm{MoO}_{3} / \mathrm{SiO}_{2}-\mathrm{Al}_{2} \mathrm{O}_{3}$ and $\mathrm{MoO}_{3} / \mathrm{Al}_{2} \mathrm{O}_{3}$ sys- 


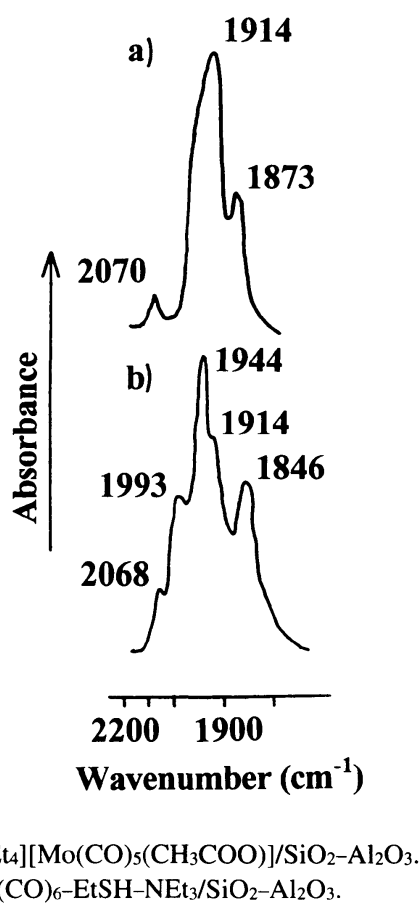

Fig. 4 FTIR Spectra of Silica-Alumina Supported Molybdenum Carbonyls

tems were also very similar. As clearly shown in Fig. 3, the apparent activation energies of silica-alumina supported anionic metal carbonyl systems were much larger than those of the conventional systems. Therefore, the catalytic activities of the former were greater than those of the latter above about $260^{\circ} \mathrm{C}$. The selectivity for BP of $\left[\mathrm{NEt}_{4}\right]\left[\mathrm{Mo}(\mathrm{CO})_{5}\left(\mathrm{OOCCH}_{3}\right)\right] /$ $\mathrm{SiO}_{2}-\mathrm{Al}_{2} \mathrm{O}_{3}$ was much lower than that of $\mathrm{MoO}_{3} / \mathrm{Al}_{2} \mathrm{O}_{3}$ in the temperature range investigated. Hydrogenation of the aromatic ring, as well as desulfurization, is one of the key reactions for achieving the deep desulfurization of methyl-substituted $\mathrm{DBT}^{41)}$. As mentioned above, silica-alumina supported catalysts have higher selectivities for $\mathrm{CHB}$, that is, higher activities for the hydrogenation of the aromatic ring than alumina-supported catalysts, indicating that silica-alumina supported ones may be more suitable for deep desulfurization processes.

The FTIR spectra of silica-alumina supported molybdenum carbonyls before activation are shown in Fig. 4. $\left[\mathrm{Mo}(\mathrm{CO})_{5}\left(\mathrm{OOCCH}_{3}\right)\right]^{-}$supported on silicaalumina (Fig. 4 a)) showed three absorptions at 2070 (w), 1914 (vs, b = broad) and $1873(\mathrm{~m}) \mathrm{cm}^{-1}$. The IR spectrum of $\left[\mathrm{Mo}(\mathrm{CO})_{5}\left(\mathrm{OOCCH}_{3}\right)\right]^{-}$obtained as a Nujol mull showed four absorptions at 2035 ( $\mathrm{vw}=$ very weak), 1985 ( $\mathrm{s}=$ strong), 1930 (vs = very strong) and $1857(\mathrm{~m}=$ medium $) \mathrm{cm}^{-1}{ }^{40}$ ). Although the configuration of carbonyl ligands in $\left[\mathrm{Mo}(\mathrm{CO})_{5}\left(\mathrm{OOCCH}_{3}\right)\right]^{-}$ seemed to change with the deposition of the complex onto silica-alumina, the IR spectrum confirmed the

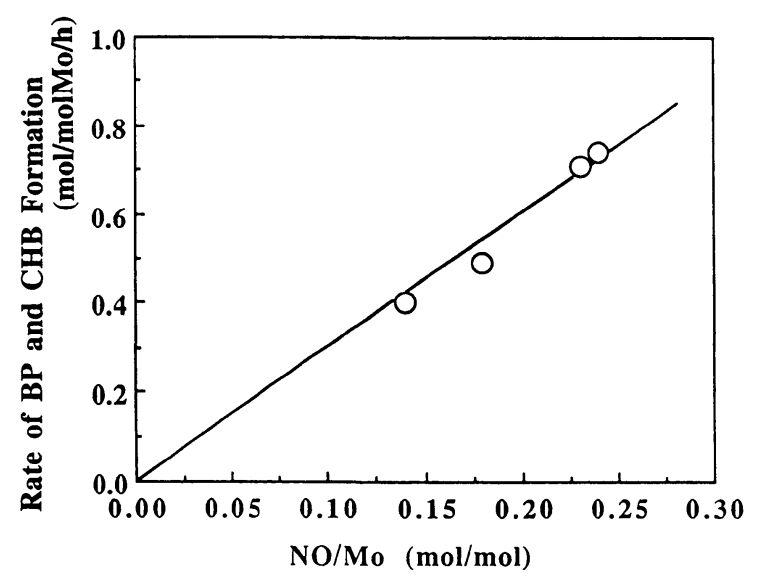

Fig. 5 Effect of the Ratio of NO/Mo on HDS Rate

presence of a mononuclear anionic molybdenum carbonyl on the support. The $\mathrm{Mo}(\mathrm{CO})_{6}-\mathrm{NEt}_{3}-\mathrm{EtSH} /$ $\mathrm{SiO}_{2}-\mathrm{Al}_{2} \mathrm{O}_{3}$ system showed five absorptions at 2068 (w), 1993 (m), 1944 (vs), 1914 (m, sh = shoulder) and $1846(\mathrm{~m}) \mathrm{cm}^{-1}$. The IR spectrum of $\left[\mathrm{Mo}_{2}(\mathrm{CO})_{10} \mathrm{SCH}_{3}\right]^{-}$ obtained as a THF solution showed six absorptions at 2059 (w), 2045 (m), 1974 (w, sh), 1942 (vs), 1916 (m) and $1857(\mathrm{~s}) \mathrm{cm}^{-1} \mathrm{42}^{4}$. This also confirmed the presence of a dinuclear molybdenum carbonyl on the support.

NO adsorption on catalysts derived from silica-alumina supported molybdenum carbonyls was larger than on sulfided $\mathrm{MoO}_{3} / \mathrm{SiO}_{2}-\mathrm{Al}_{2} \mathrm{O}_{3}$ and $\mathrm{MoO}_{3} / \mathrm{Al}_{2} \mathrm{O}_{3}$, indicating that the catalysts derived from supported metal carbonyls have higher dispersion of the molybdenum species than the conventional catalysts. Such high dispersion of molybdenum species may be related to the selectivity for BP of the catalyst, which is different from that of sulfided catalysts. For sulfided catalysts, the relationship between NO adsorption (NO/Mo) and the rate of HDS of DBT into BP and CHB is compared in Fig. 5. There was a linear relationship between adsorbed NO per molybdenum loaded and the rate of HDS. NO chemisorption apparently reflects the number of active sites for HDS as well as the extent of surface coverage or dispersion of Mo. There was no linear correlation between NO adsorption and HDS activity for alumina-supported $\mathrm{Mo}, \mathrm{Ni}-\mathrm{Mo}$ or Co-Mo catalyst, probably because the total NO uptake involves different contributions from the chemisorbed NO on Mo, $\mathrm{Ni}$ (or Co), and Ni-Mo (or Co-Mo) sites ${ }^{33), 43), 44)}$. NO chemisorption on alumina-supported catalysts probably reflects the extent of surface coverage or dispersion of Mo rather than the number of active sites for HDS. In contrast, NO chemisorption on silica-alumina supported catalysts is likely to reflect the number of active sites for HDS. 


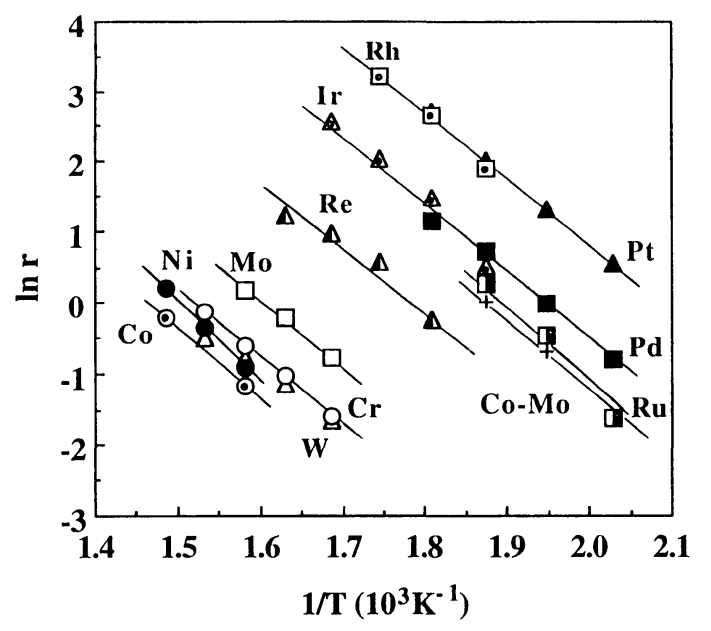

$r$ : HDS rate $(\mathrm{mol}-\mathrm{DBT} / \mathrm{mol}-\mathrm{metal} \cdot \mathrm{h})$. Pressure $50 \mathrm{~kg} / \mathrm{cm}^{2}$, WHSV $28 \mathrm{~h}^{-1}$, Gas/Oil $786 \mathrm{~N} / / l$ (except for Ru Co-Mo catalysts: WHSV $70 \mathrm{~h}^{-1}$, gas/oil $1132 \mathrm{~N} l / l$ ), DBT $1.0 \mathrm{wt} \%$, solvent decalin. $\mathrm{Cr} / \mathrm{Al}_{2} \mathrm{O}_{3}\left(\mathrm{CrO}_{3}: 11 \mathrm{wt} \%, \mathrm{Cr}\left(\mathrm{NO}_{3}\right)_{3} \cdot 9 \mathrm{H}_{2} \mathrm{O}\right), \square \mathrm{Mo} / \mathrm{Al}_{2} \mathrm{O}_{3}$ $\left(\mathrm{MoO}_{3}: 12.4 \mathrm{wt} \%,\left(\mathrm{NH}_{4}\right)_{6} \mathrm{Mo}_{7} \mathrm{O}_{24} \cdot 4 \mathrm{H}_{2} \mathrm{O}\right), \triangle \mathrm{W} / \mathrm{Al}_{2} \mathrm{O}_{3}\left(\mathrm{WO}_{3}\right.$ : $\left.28 \mathrm{wt} \%, \mathrm{H}_{26} \mathrm{~N}_{6} \mathrm{~W}_{12} \mathrm{O}_{41}\right), \triangle \mathrm{Re} / \mathrm{Al}_{2} \mathrm{O}_{3}\left(\mathrm{Re}: 2 \mathrm{wt} \%, \operatorname{Re}_{2}(\mathrm{CO})_{10}\right)$, - $\mathrm{Ru} / \mathrm{Al}_{2} \mathrm{O}_{3}\left(\mathrm{Ru}: 8 \mathrm{wt} \%, \mathrm{Ru}_{3}(\mathrm{CO})_{12}+6 \mathrm{CsOH}\right), \odot \mathrm{Co} / \mathrm{Al}_{2} \mathrm{O}_{3}$ (CoO: $4 \mathrm{wt} \%, \mathrm{Co}\left(\mathrm{NO}_{3}\right)_{2} \cdot 6 \mathrm{H}_{2} \mathrm{O}$ ), $\bullet \mathrm{Rh} / \mathrm{Al}_{2} \mathrm{O}_{3}$ (Rh: $0.25 \mathrm{wt} \%$, $\left.\mathrm{Rh}_{6}(\mathrm{CO})_{16}+6 \mathrm{CsOH}\right), \Delta \mathrm{Ir} / \mathrm{Al}_{2} \mathrm{O}_{3}$ (Ir: $2 \mathrm{wt} \%, \mathrm{IrCl}_{4} \cdot \mathrm{H}_{2} \mathrm{O}$ ), $\mathrm{Ni} / \mathrm{Al}_{2} \mathrm{O}_{3}$ (NiO: 3 wt $\%, \mathrm{Ni}\left(\mathrm{NO}_{3}\right)_{2} \cdot 6 \mathrm{H}_{2} \mathrm{O}$ ), $\mathrm{Pd} / \mathrm{Al}_{2} \mathrm{O}_{3}$ (Pd: 1 wt $\left.\%, \mathrm{PdCl}_{2}\right), \Delta \mathrm{Pt} / \mathrm{Al}_{2} \mathrm{O}_{3}\left(\mathrm{Pt}: 1 \mathrm{wt} \%, \mathrm{H}_{2} \mathrm{PtCl}_{6} \cdot 6 \mathrm{H}_{2} \mathrm{O}\right)$, $+\mathrm{Co}-$ $\mathrm{Mo} / \mathrm{Al}_{2} \mathrm{O}_{3}\left(\mathrm{MoO}_{3}: 12.4 \mathrm{wt} \%, \mathrm{CoO}: 3.8 \mathrm{wt} \%,\left(\mathrm{NH}_{4}\right)_{6} \mathrm{Mo}_{7} \mathrm{O}_{24}\right.$. $\left.4 \mathrm{H}_{2} \mathrm{O}, \mathrm{Co}\left(\mathrm{NO}_{3}\right)_{2} \cdot 6 \mathrm{H}_{2} \mathrm{O}\right)$.

Fig. 6 Arrhenius Plots of DBT HDS on Alumina-supported Transition Metal Catalysts

\section{HDS Catalysts Using Noble Metals}

HDS catalysts with higher activity have generally been developed by extending the surface area of the alumina and increasing the metal loading on the conventional alumina-supported CoMo, NiMo and NiW catalysts, there is a limit to the surface area of alumina which is difficult to exceed. Ruthenium sulfide is most active of the transition metal sulfides for HDS of $\mathrm{DBT}^{45)}$, and much attention has been focused on HDS, hydrogenation, and hydrodenitrogenation catalyzed by noble metal sulfides, especially ruthenium sulfide, to develop a new generation of catalysts with different properties from the current $\mathrm{Co}, \mathrm{Ni}, \mathrm{Mo}$ and W-based types $^{46)} \sim 65$ ).

Deposition of ruthenium sulfide onto supports with large surface areas, such as alumina, silica, silica-alumina, zeolite etc., is expected to increase the catalytic activity per ruthenium atom. This approach is also economical because ruthenium is one of the noble metals. HDS catalyzed by supported ruthenium sulfide has already been investigated ${ }^{52) \sim 58), 67) \sim 69)}$. The HDS activity of these catalysts was rather low probably because sulfidation of the ruthenium species was incomplete and $\mathrm{RuS}_{2}$ on alumina is unstable in a hydro-

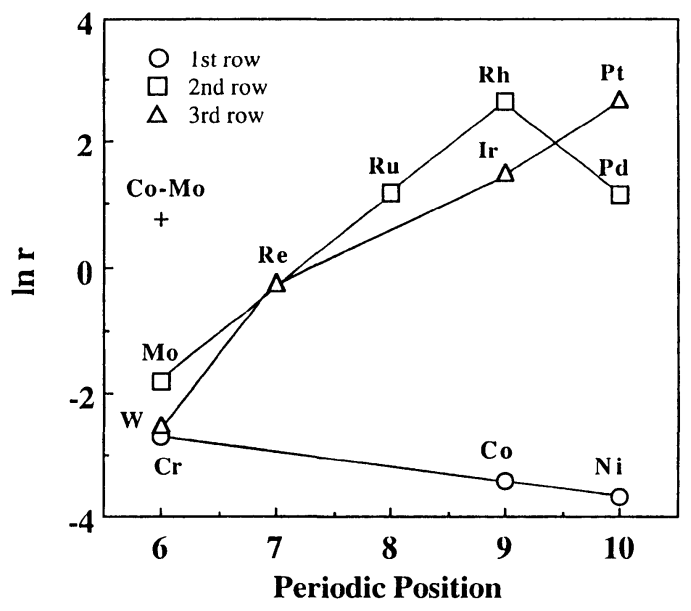

$r(\mathrm{~mol}-\mathrm{DBT} / \mathrm{mol}$-metal $\cdot \mathrm{h})$ : HDS rate at $280^{\circ} \mathrm{C}$ adopted from Fig. 6. Values of $r$ for supported $\mathrm{Cr}, \mathrm{Mo}, \mathrm{W}, \mathrm{Ru}, \mathrm{Ni}$ or Co-Mo catalysts were estimated based on the data in Fig. 6.

Fig. 7 Periodic Trends in HDS of DBT Catalyzed by Various Supported Transition Metals

gen atmosphere. Further, the catalytic activity of the catalyst derived from supported $\mathrm{Ru}_{3}(\mathrm{CO})_{12}$ was often lower than that derived from supported $\mathrm{RuCl}_{3}{ }^{69)} \sim 71$ ). The sulfidation conditions will also affect the hydrogenation and HDS activities of ruthenium catalysts ${ }^{57) ~-59)}$. However, most of these HDS reactions were performed under atmospheric pressure, and the activities of catalysts derived from supported ruthenium in a pressurized flow system have not yet been clarified in comparison with those of $\mathrm{Co}-\mathrm{Mo} / \mathrm{Al}_{2} \mathrm{O}_{3}$ and $\mathrm{Ni}-\mathrm{Mo} /$ $\mathrm{Al}_{2} \mathrm{O}_{3}$. Further, extremely rapid deactivation may occur with Ru/alumina and $\mathrm{Ru} / \mathrm{Y}$-zeolite ${ }^{61)}$. Recently, HDS and HDN of coal-derived naphtha catalyzed by alumina and zeolite-supported ruthenium sulfide catalysts in a pressurized flow system were reported ${ }^{62)}$. The HDN activities per gram of catalyst were higher than those of $\mathrm{Co}-\mathrm{Mo} / \mathrm{Al}_{2} \mathrm{O}_{3}$ and $\mathrm{Ni}-\mathrm{Mo} / \mathrm{Al}_{2} \mathrm{O}_{3}$ catalysts, although the HDS activities per gram of catalyst were lower than those of $\mathrm{Co}-\mathrm{Mo} / \mathrm{Al}_{2} \mathrm{O}_{3}$ and $\mathrm{Ni}-\mathrm{Mo} / \mathrm{Al}_{2} \mathrm{O}_{3}$ catalysts. Alumina-supported $\mathrm{Ni}-\mathrm{Ru}-\mathrm{S}$ catalyst has a very high hydrogenation activity compared with a commercial alumina-supported Ni-Mo catalyst ${ }^{64)}$. The HDS catalysts derived from $\mathrm{H}_{2} \mathrm{SRu}_{3}(\mathrm{CO})_{9}$, $\mathrm{HSRu}_{2} \mathrm{Co}(\mathrm{CO})_{9}, \mathrm{SRuCo}_{2}(\mathrm{CO})_{9}$, and $\left[\mathrm{Co}_{3} \mathrm{~S}_{2}(\mathrm{CO})_{7}\right]_{2}$ supported on carbon and alumina were also evaluated ${ }^{65)}$. Among catalysts sulfided at $400^{\circ} \mathrm{C}$, the mixed metal cluster catalysts were less active for thiophene HDS than catalysts containing only one metal component. The carbon-supported catalysts were more active for thiophene HDS and more selective for butane formation than alumina-supported catalysts. Noble metals other than ruthenium are also active for HDS of thiophene ${ }^{55), 56), 72) ~-76)}$. 


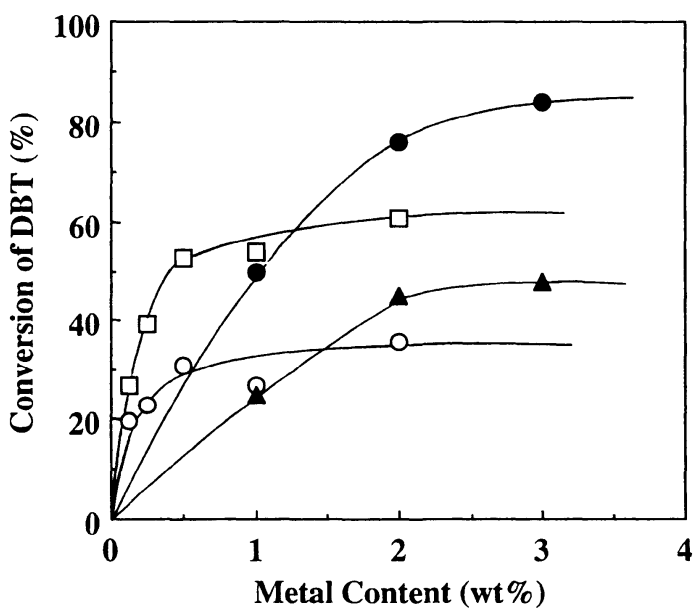

Pressure $50 \mathrm{~kg} / \mathrm{cm}^{2}$, WHSV $28 \mathrm{~h}^{-1}$, Gas/Oil $786 \mathrm{~N} / / \mathrm{l}$. $\mathrm{Rh} / \mathrm{Al}_{2} \mathrm{O}_{3}\left(\mathrm{Rh}_{6}(\mathrm{CO})_{16}+6 \mathrm{CsOH}\right): \bigcirc 280^{\circ} \mathrm{C}, \square 300^{\circ} \mathrm{C}$. $\quad \mathrm{Pt} / \mathrm{Al}_{2} \mathrm{O}_{3}$ $\left(\mathrm{H}_{2} \mathrm{PtCl}_{6} \cdot 6 \mathrm{H}_{2} \mathrm{O}\right): \Delta 260^{\circ} \mathrm{C}, 280^{\circ} \mathrm{C}$.

Fig. 8 Effect of Metal Content on Conversion of DBT

The authors have investigated HDS of DBT on alumina-supported transition metal catalysts. A linear relationship was found between the HDS activity and the metal content in the catalyst. Figures 6 and 7 show the Arrhenius plots and the periodic trends, respectively ${ }^{1)}$. Similar to carbon-supported catalysts, volcano curves were observed in the second row and alumina-supported $\mathrm{Rh}$ catalyst showed the highest HDS activity per amount of metal loaded. Further, group 810 transition metals in the second and third rows showed relatively high catalytic activities. As shown in Fig. 8, the activity of the Rh catalyst increased linearly up to $1 \mathrm{wt} \%$ but leveled off over $1 \mathrm{wt} \%$. Pt catalyst showed a similar trend. In contrast, the activities of Mo catalysts increased linearly with increasing metal content even at more than $8 \mathrm{wt} \%$. The activity of the $\mathrm{Ru}$ catalyst increases at least up to $16 \mathrm{wt} \%$ (not shown in Fig. 8) ${ }^{77)}$. These results show that not only the intrinsic activity of a metal but also the capacity of a support for metal loading is very important to obtain high activity per unit catalyst weight.

\section{Catalysts for Hydrodesulfurization Prepared from Alumina-supported Ruthenium Carbonyl- Alkali Metal Hydroxide Systems}

Catalysts derived from supported anionic molybdenum carbonyls are more active for HDS of DBT than conventional sulfided molybdena alumina and aluminasupported neutral molybdenum hexacarbonyl catalysts ${ }^{33), 34), 38), 39), 78)}$. Alumina-supported anionic molybdenum carbonyls inhibit the sintering and sublimation of molybdenum species to maintain the dispersion of molybdenum sulfide on the support. These techniques were applied to the preparation of supported ruthenium carbonyls for HDS of DBT. Anionic ruthenium carbonyl complexes were prepared because anionic molybdenum complexes were effective for HDS of DBT catalyzed by supported molybdenum carbonyls. Addition of alkali metal remarkably increased the HDS activity. The use of alumina-supported anionic ruthenium carbonyls inhibited the sintering of ruthenium species and maintained the dispersion of ruthenium species on the support. Here, the HDS of DBT on alkali-promoted ruthenium catalysts in a pressurized flow reactor is described in detail.

The activity of the catalyst derived from the aluminasupported $\mathrm{Ru}_{3}(\mathrm{CO})_{12}$-alkali metal hydroxide system, where $\mathrm{Ru}_{3}(\mathrm{CO})_{12}$ reacts with alkali metal hydroxide to give an anionic ruthenium hydride complex $\mathrm{M}\left[\mathrm{HRu}_{3}(\mathrm{CO})_{11}\right](\mathrm{M}=$ alkali metal $)$, was compared with that of catalysts derived from alkali promoted aluminasupported $\mathrm{Ru}(\mathrm{acac})_{3}$ and $\mathrm{RuCl}_{3}$. The addition of alkali metal remarkably increased the activities of ruthenium catalysts, and the catalyst derived from the aluminasupported anionic ruthenium carbonyl is the most

Table 2 Hydrodesulfurization of Dibenzothiophene Catalyzed by Alumina-supported Ruthenium Catalysts ${ }^{\text {a) }}$

\begin{tabular}{|c|c|c|c|c|c|}
\hline Run & Catalyst & $\begin{array}{c}\text { Conv. of } \\
\text { DBT } \\
{[\%]}\end{array}$ & $\begin{array}{c}\text { Conv. of } \\
\text { DBT to BP } \\
{[\%]}\end{array}$ & $\begin{array}{c}\text { Conv. of } \\
\text { DBT to CHB } \\
{[\%]}\end{array}$ & $\begin{array}{c}\text { Selectivity } \\
\text { of BP } \\
{[\%]}\end{array}$ \\
\hline 1 & $\mathrm{Ru}_{3}(\mathrm{CO})_{12} / \mathrm{Al}_{2} \mathrm{O}_{3}$ & 44 & 38 & 6 & 86 \\
\hline 2 & $\left.\mathrm{Ru}(\mathrm{acac})_{3} / \mathrm{Al}_{2} \mathrm{O}_{3} \mathrm{~b}\right)$ & 35 & 30 & 5 & 87 \\
\hline 3 & $\mathrm{RuCl}_{3} / \mathrm{Al}_{2} \mathrm{O}_{3}{ }^{\mathrm{c})}$ & 29 & 23 & 6 & 80 \\
\hline 4 & $\mathrm{Ru}_{3}(\mathrm{CO})_{12}-3 \mathrm{NaOH} / \mathrm{Al}_{2} \mathrm{O}_{3}$ & 71 & 67 & 4 & 95 \\
\hline 5 & $\mathrm{Ru}(\text { acac })_{3}-\mathrm{NaOH} / \mathrm{Al}_{2} \mathrm{O}_{3}$ & 43 & 40 & 3 & 93 \\
\hline 6 & $\mathrm{RuCl}_{3} / \mathrm{Al}_{2} \mathrm{O}_{3}+\mathrm{NaOH}^{\mathrm{d})}$ & 15 & 14 & 1 & 95 \\
\hline 7 & $\mathrm{Ru}_{3}(\mathrm{CO})_{12} / \mathrm{Al}_{2} \mathrm{O}_{3}+3 \mathrm{NaOH}^{\mathrm{e})}$ & 43 & 40 & 3 & 94 \\
\hline 8 & $3 \mathrm{NaOH} / \mathrm{Al}_{2} \mathrm{O}_{3}+\mathrm{Ru}_{3}(\mathrm{CO})_{12}{ }^{\mathrm{f}}$ & 32 & 30 & 2 & 94 \\
\hline
\end{tabular}

a) Reaction temp. $300^{\circ} \mathrm{C}$, Pressure $50 \mathrm{~kg} / \mathrm{cm}^{2}$, WHSV $16.5 \mathrm{~h}^{-1}$, Cat. $0.50 \mathrm{~g}, \mathrm{H}_{2} 18 \mathrm{l} / \mathrm{h}$, Amount of Ru $3(\mathrm{CO})_{12} 0.13 \mathrm{mmol}$; presulfided by $\mathrm{H}_{2} \mathrm{~S}$ in $\mathrm{H}_{2}$ at $300^{\circ} \mathrm{C}\left(\mathrm{H}_{2} \mathrm{~S} 3 \%\right)$. b) acac = acetylacetonate. c) Presulfided by $\mathrm{H}_{2} \mathrm{~S}$ in $\mathrm{H}_{2}$ at $400^{\circ} \mathrm{C}\left(\mathrm{H}_{2} \mathrm{~S} 3 \%\right)$. d) Initially $\mathrm{RuCl}$ was supported on $\mathrm{Al}_{2} \mathrm{O}_{3}$ and then $\mathrm{NaOH}$ was added at $\mathrm{Ru} / \mathrm{Na}=1$. e) Initially $\mathrm{Ru}_{3}(\mathrm{CO})_{12}$ was supported on $\mathrm{Al}_{2} \mathrm{O}_{3}$ and then $\mathrm{NaOH}$ was added at $\mathrm{Ru} / \mathrm{Na}=1$. f) Initially $\mathrm{NaOH}$ was supported on $\mathrm{Al}_{2} \mathrm{O}_{3}$ and then $\mathrm{Ru}_{3}(\mathrm{CO})_{12}$ was added at $\mathrm{Ru} / \mathrm{Na}=1$. 


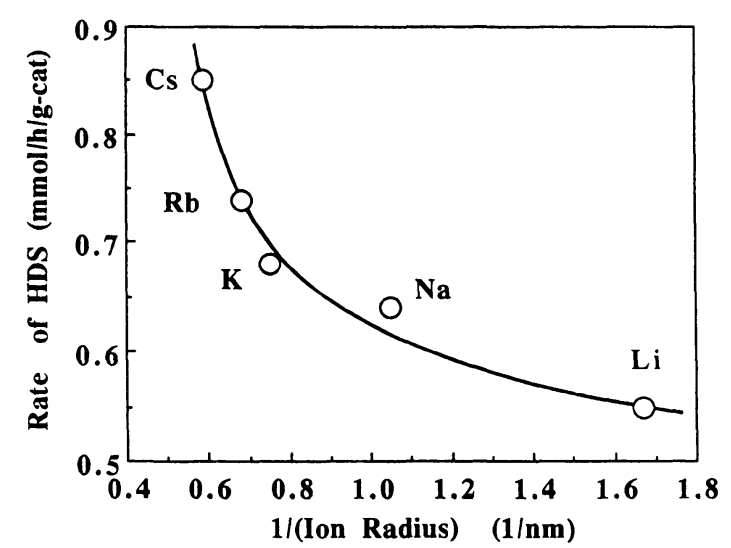

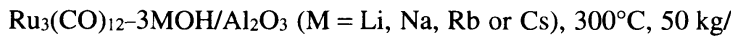
$\mathrm{cm}^{2}, \mathrm{H}_{2} 18 \mathrm{l} / \mathrm{h}$, WHSV $16.5 \mathrm{~h}^{-1}$; initial concentration of DBT in xylene, $1.0 \mathrm{wt} \%$, catalyst $0.5 \mathrm{~g}$, Ru $8 \mathrm{wt} \%$.

Fig. 9 Rate of HDS vs. 1/(Ion Radius)

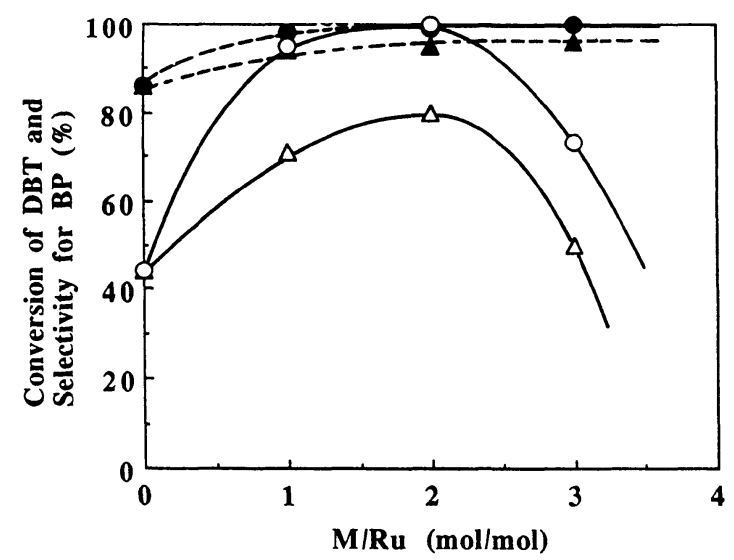

Conversion of DBT: $\bigcirc \mathrm{Cs}, \triangle \mathrm{Na} . \quad$ Selectivity for BP: Cs, - Na. $\mathrm{Ru}_{3}(\mathrm{CO})_{12}-n \mathrm{MOH} / \mathrm{Al}_{2} \mathrm{O}_{3}(\mathrm{M}=\mathrm{Na}$ or $\mathrm{Cs}), 300^{\circ} \mathrm{C}, 50$ $\mathrm{kg} / \mathrm{cm}^{2}, \mathrm{H}_{2} 18 \mathrm{l} / \mathrm{h}$, WHSV $16.5 \mathrm{~h}^{-1}$; initial concentration of DBT in xylene, $1.0 \mathrm{wt} \%$, catalyst $0.5 \mathrm{~g}, \mathrm{Ru} 8 \mathrm{wt} \%$.

Fig. 10 Effect of M/Ru Ratio on the Conversion of DBT and the Selectivity for BP

active for HDS of DBT ${ }^{79,80)}$.

Initially, the effects of addition of $\mathrm{NaOH}$ to the alumina-supported ruthenium catalysts were investigated under the following conditions: $300^{\circ} \mathrm{C} ; 50 \mathrm{~kg} / \mathrm{cm}^{2} ; \mathrm{H}_{2}$ $18 \mathrm{l} / \mathrm{h}$; WHSV, $16.5 \mathrm{~h}^{-1}$; initial concentration of DBT, $1.0 \mathrm{wt} \%$ in xylene; catalyst, $0.5 \mathrm{~g}$. Alumina-supported ruthenium catalysts examined were active for HDS and the products were $\mathrm{BP}$ and $\mathrm{CHB}$. The results are shown in Table 2. In the absence of $\mathrm{NaOH}$ (runs 13 ), the activities of catalysts derived from alumina-supported ruthenium decreased in the order $\mathrm{Ru}_{3}(\mathrm{CO})_{12}>$ $\mathrm{Ru}(\text { acac })_{3}>\mathrm{RuCl}_{3}$. When $\mathrm{Ru}_{3}(\mathrm{CO})_{12}$ was reacted with $\mathrm{NaOH}$ and then supported on alumina (run 4), the catalytic activity remarkably increased and the conver-

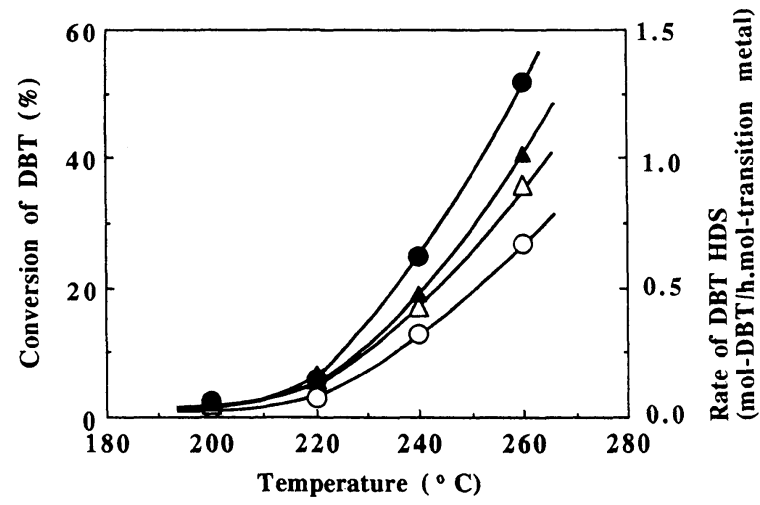

Conversion of DBT: $\bigcirc \mathrm{Ru}-\mathrm{Cs} / \mathrm{Al}, \triangle \mathrm{Co}-\mathrm{Mo} / \mathrm{Al}$. Rate of DBT HDS: $\mathrm{Ru}-\mathrm{Cs} / \mathrm{Al}, \Delta \mathrm{Co}-\mathrm{Mo} / \mathrm{Al}$. $\mathrm{Ru}_{3}(\mathrm{CO})_{12}-6 \mathrm{CsOH} /$ $\mathrm{Al}_{2} \mathrm{O}_{3}(\mathrm{Ru}, 8 \mathrm{wt} \%), \mathrm{Co}-\mathrm{Mo} / \mathrm{Al}_{2} \mathrm{O}_{3}(\mathrm{Mo}, 8 \mathrm{wt} \%, \mathrm{Co} / \mathrm{Mo}=0.58$ ), $50 \mathrm{~kg} / \mathrm{cm}^{2}, \mathrm{H}_{2} 18 \mathrm{l} / \mathrm{h}$, WHSV $70 \mathrm{~h}^{-1}$; initial concentration of DBT in decalin, $1.0 \mathrm{wt} \%$.

Fig. 11 Effect of Temperature on the Conversion of DBT and the Rate of HDS of DBT

sion of DBT was $71 \%$. The catalyst in this system was prepared by reaction of $\mathrm{Ru}_{3}(\mathrm{CO})_{12}$ with sodium hydroxide to give $\mathrm{Na}\left[\mathrm{HRu}_{3}(\mathrm{CO})_{11}\right]$ quantitatively which was confirmed by FTIR (2076 (w), 2022 (vs), 1993 (s), $1964(\mathrm{~m}), 1642$ (w) $\mathrm{cm}^{-1}$ in methanol $)^{81)}$. The $\mathrm{Ru}(\mathrm{acac})_{3}-\mathrm{NaOH} / \mathrm{Al}_{2} \mathrm{O}_{3}$ system had slightly increased activity (run 5) compared to the $\mathrm{Ru}(\text { acac })_{3} / \mathrm{Al}_{2} \mathrm{O}_{3}$ system. When $\mathrm{NaOH}$ was added to the calcined $\mathrm{RuCl}_{3} /$ $\mathrm{Al}_{2} \mathrm{O}_{3}$, the conversion of DBT decreased (run 6). When $\mathrm{Ru}_{3}(\mathrm{CO})_{12}$ and/or $\mathrm{NaOH}$ were supported on alumina in sequence, no significant increase in the catalytic activity was observed (runs 7,8 ). This suggests that the location of the sodium close to the ruthenium species by the presulfiding of $\mathrm{Na}\left[\mathrm{HRu}_{3}(\mathrm{CO})_{11}\right]$ supported on alumina may be intrinsic to the high catalytic activity. The addition of $\mathrm{NaOH}$ increased the selectivity for BP in every catalyst, independent of the activity. Presence of $\mathrm{NaOH}$ seems to poison the active sites for hydrogenation of an aromatic ring, without affecting the active sites for desulfurization. Further, the result indicates that the active sites for hydrogenation of an aromatic ring are different from those for hydrodesulfurization.

Change of the alkali metal in the alumina-supported $\mathrm{Ru}_{3}(\mathrm{CO})_{12}$-alkali metal hydroxide system showed that the conversion of DBT increased in the order $\mathrm{Li}<\mathrm{Na}<$ $\mathrm{K}<\mathrm{Rb}<\mathrm{Cs}$, which seems to be related to the ion radius of the alkali metal. When the rate of HDS of DBT was plotted against the reciprocal of the ion radius of the alkali metal as shown in Fig. 9, the rate markedly increased for large ions such as $\mathrm{Cs}$ and $\mathrm{Rb}$, indicating that ion radius affects the catalytic activity. As shown in Fig. 10, the conversion of DBT and the selectivity for $\mathrm{BP}$ increased with greater $\mathrm{M} / \mathrm{Ru}$ molar 


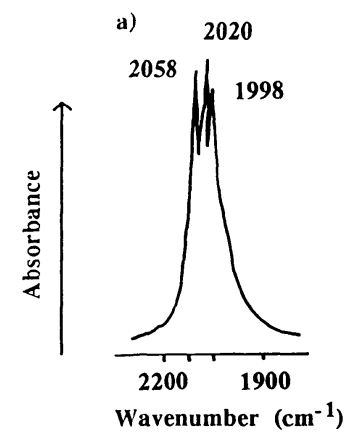

b)

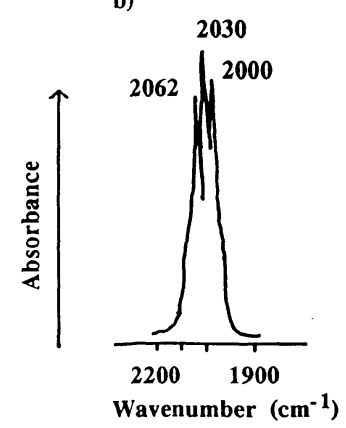

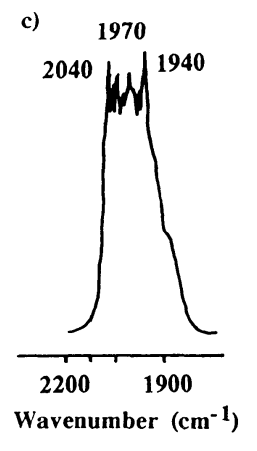

d)

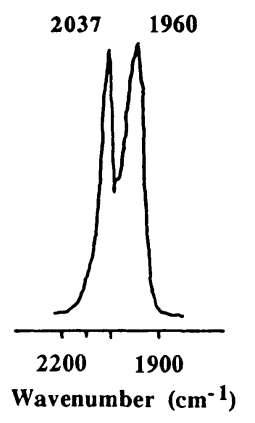

a) $\mathrm{Ru}_{3}(\mathrm{CO})_{12} / \mathrm{Al}_{2} \mathrm{O}_{3}$. b) $\mathrm{Ru}_{3}(\mathrm{CO})_{12}-3 \mathrm{CsOH} / \mathrm{Al}_{2} \mathrm{O}_{3}$. c) $\mathrm{Ru}_{3}(\mathrm{CO})_{12-}$ $6 \mathrm{CsOH} / \mathrm{Al}_{2} \mathrm{O}_{3}$. d) $\mathrm{Ru}_{3}(\mathrm{CO})_{12}-9 \mathrm{CsOH} / \mathrm{Al}_{2} \mathrm{O}_{3}$.

Fig. 12 FTIR Spectra of $\mathrm{Ru}_{3}(\mathrm{CO})_{12}-n \mathrm{CsOH} / \mathrm{Al}_{2} \mathrm{O}_{3}$

ratio $(\mathrm{M}=\mathrm{Na}$ or $\mathrm{Cs})$. Both values for $\mathrm{Cs}$ were greater than those for $\mathrm{Na}$ at every $\mathrm{M} / \mathrm{Ru}$ ratio. Furthermore, $\mathrm{Cs}$ showed a maximum at $\mathrm{M} / \mathrm{Ru}=2$ which was greater than the amount of alkali metal hydroxide needed to form $\mathrm{M}\left[\mathrm{HRu}_{3}(\mathrm{CO})_{11}\right] \quad(\mathrm{M} / \mathrm{Ru}=1)$, suggesting that excess of alkali metals is consumed by alumina. Further addition of alkali metals decreased the conversion, probably because a such large amount of alkali metal would shield the active ruthenium species.

To compare the activities of catalysts derived from $\mathrm{Ru}_{3}(\mathrm{CO})_{12}-6 \mathrm{CsOH} / \mathrm{Al}_{2} \mathrm{O}_{3}$ and commercial $\mathrm{Co}-\mathrm{Mo} /$ $\mathrm{Al}_{2} \mathrm{O}_{3}$, HDS of DBT was performed under the following conditions: $200-260^{\circ} \mathrm{C} ; 50 \mathrm{~kg} / \mathrm{cm}^{2} ; \mathrm{H}_{2}, 18 \mathrm{l} / \mathrm{h}$; WHSV, $70 \mathrm{~h}^{-1}$; initial concentration of DBT, $1.0 \mathrm{wt} \%$ in decalin; catalyst, $0.2 \mathrm{~g}$. The results are shown in Fig. 11. Although conversion of DBT over the ruthenium catalyst was slightly less than that over $\mathrm{Co}-\mathrm{Mo} /$ $\mathrm{Al}_{2} \mathrm{O}_{3}$, the HDS rate of DBT per supported amount of transition metal of the former was greater than that of the latter.

The FTIR spectra of the catalyst precursors are shown in Fig. 12. $\mathrm{Ru}_{3}(\mathrm{CO})_{12}$ supported on alumina showed three peaks at 1998 (s), 2020 (vs) and 2058 (vs) $\mathrm{cm}^{-1} . \quad \mathrm{Ru}_{3}(\mathrm{CO})_{12}$ without alumina showed almost the same peaks, so $\mathrm{Ru}_{3}(\mathrm{CO})_{12}$ was located only on alumina surface in the $\mathrm{Ru}_{3}(\mathrm{CO})_{12} / \mathrm{Al}_{2} \mathrm{O}_{3}$ system. When $\mathrm{Ru}_{3}(\mathrm{CO})_{12}$ was treated with 3 fold $\mathrm{CsOH}$ in methanol, all $\mathrm{Ru}_{3}(\mathrm{CO})_{12}$ was converted to $\mathrm{Cs}\left[\mathrm{HRu}_{3}(\mathrm{CO})_{11}\right]$. The

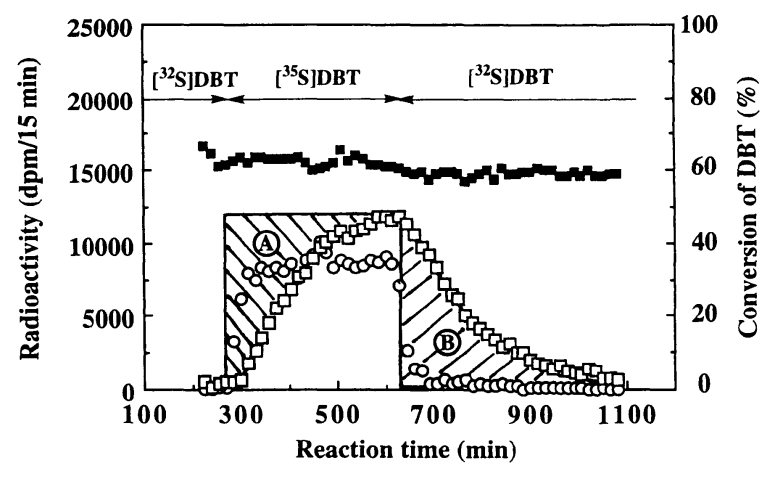

$\mathrm{Ru}_{3}(\mathrm{CO})_{12}-6 \mathrm{CsOH} / \gamma-\mathrm{Al}_{2} \mathrm{O}_{3}, \bigcirc\left[{ }^{35} \mathrm{~S}\right] \mathrm{DBT}, \square\left[{ }^{35} \mathrm{~S}\right] \mathrm{H}_{2} \mathrm{~S}$, $\square$ Conversion (\%). $280^{\circ} \mathrm{C}, 50 \mathrm{~kg} / \mathrm{cm}^{2}$, WHSV $14 \mathrm{~h}^{-1}$, Gas flow 18 l/h.

Fig. 13 Change in Radioactivity with Reaction Time

methanol solution of $\mathrm{Cs}\left[\mathrm{HRu}_{3}(\mathrm{CO})_{11}\right]$ showed the same FTIR peaks as $\mathrm{Na}\left[\mathrm{HRu}_{3}(\mathrm{CO})_{11}\right]$ mentioned above. However, $\mathrm{Cs}\left[\mathrm{HRu}_{3}(\mathrm{CO})_{11}\right]$ supported on alumina showed three peaks at 2000 (s), 2030 (vs) and 2062 (s) $\mathrm{cm}^{-1}$, indicating that $\mathrm{Cs}\left[\mathrm{HRu}_{3}(\mathrm{CO})_{11}\right]$ had reacted with the acid sites on the alumina support to form $\mathrm{Ru}_{3}(\mathrm{CO})_{12}$ on the alumina. This result shows that the location of cesium close to ruthenium species is intrinsic to the increased activity, even when $\mathrm{Ru}_{3}(\mathrm{CO})_{12}$ is formed. When $\mathrm{Ru}_{3}(\mathrm{CO})_{12}$ was treated with 6 fold $\mathrm{CsOH}$ in methanol and supported on alumina, $\mathrm{Ru}_{3}(\mathrm{CO})_{12}$ was not formed and anionic species were maintained on the alumina, since peaks with wavenumbers lower than those of $\mathrm{Ru}_{3}(\mathrm{CO})_{12}$ were observed. This result shows that the maintenance of the anionic species on alumina as well as the location of cesium close to ruthenium species are also essential to the increased activity. When $\mathrm{Ru}_{3}(\mathrm{CO})_{12}$ was treated with 9 fold $\mathrm{CsOH}$ in methanol and was supported on alumina, anionic species were also maintained as shown in Fig. $12 \mathrm{~d}$ ). However, the trinuclear anionic $\left[\mathrm{HRu}_{3}(\mathrm{CO})_{11}\right]^{-}$apparently cannot be maintained on alumina, probably because the amount of $\mathrm{CsOH}$ added was too great to maintain the structure. Although it is not clear whether the trinuclear structure is essential to obtain the high catalytic activity, the addition of excess amount of cesium will shield the active ruthenium species and decrease the activity.

\section{Hydrodesulfurization of ${ }^{35}$ S-Labeled Dibenzoth- iophene on Alumina-supported Ruthenium Sulfide-Cesium Catalysts}

Addition of the appropriate amount of alkali metals stabilizes ruthenium sulfide on a support even under a hydrogen atmosphere to increase the HDS activity ${ }^{79), 80), 82), 83)}$. Understanding of the HDS mechanism requires knowledge of the behavior of sulfur on HDS 
Table 3 Hydrodesulfurization of ${ }^{35} \mathrm{~S}$-Labeled Dibenzothiophene over $\mathrm{Ru}_{3}(\mathrm{CO})_{12}-n \mathrm{CsOH} / \mathrm{Al}_{2} \mathrm{O}_{3} \mathrm{Catalysts}^{\mathrm{a}}$

\begin{tabular}{|c|c|c|c|c|c|c|c|}
\hline Run & $\begin{array}{l}\text { Catalyst } \\
(\mathrm{Ru}: \mathrm{Cs})\end{array}$ & $\begin{array}{c}\text { Conversion } \\
{[\%]}\end{array}$ & $\begin{array}{c}\text { Labile sulfur }{ }^{\text {b) }} \\
S_{\text {o }}[\mathrm{mg} / \mathrm{g} \text {-cat }]\end{array}$ & $\begin{array}{c}\text { Ratio of } \\
\text { labile sulfur } \\
S_{\mathrm{d}} / S_{\mathrm{t}}[\%]\end{array}$ & $\begin{array}{c}\text { Rate constant of } \\
\mathrm{H}_{2} \mathrm{~S} \text { release } \\
k\left[\times 10^{-2} / \mathrm{min}\right]\end{array}$ & $\begin{array}{l}\text { HDS rate } \\
{\left[\times 10^{-1} \mathrm{mg} /\right.} \\
\text { g-cat } / \mathrm{min}]\end{array}$ & $\begin{array}{c}S_{\mathrm{o}} \times k \\
{\left[\times 10^{-1} \mathrm{mg} /\right.} \\
\mathrm{g}-\mathrm{cat} / \mathrm{min}]\end{array}$ \\
\hline 1 & $1: 0$ & 50.1 & $9.2\left(\mathrm{RuS}_{0.36}\right)$ & 18 & 2.34 & 2.03 & 2.15 \\
\hline 2 & $1: 1$ & 87.7 & $17.2\left(\mathrm{RuS}_{0.68}\right)$ & 34 & 1.92 & 3.56 & 3.30 \\
\hline $3^{e)}$ & $1: 2$ & 60.0 & $30.4\left(\operatorname{RuS}_{1.20}\right)$ & 60 & 0.79 & 2.43 & 2.40 \\
\hline $4^{\mathrm{f})}$ & $1: 2$ & 70.0 & $34.3\left(\mathrm{RuS}_{1.35}\right)$ & 68 & 0.86 & 2.84 & 2.95 \\
\hline 5 & $1: 2$ & 94.0 & $38.5\left(\operatorname{RuS}_{1.52}\right)$ & 76 & 1.01 & 3.81 & 3.89 \\
\hline 6 & $1: 3$ & 52.5 & $39.3\left(\operatorname{RuS}_{1.55}\right)$ & 78 & 0.60 & 2.13 & 2.36 \\
\hline
\end{tabular}

a) Catalyst: $\mathrm{Ru}_{3}(\mathrm{CO})_{12}-n \mathrm{CsOH} / \mathrm{Al}_{2} \mathrm{O}_{3}, 0.5 \mathrm{~g}, \mathrm{Ru} 8 \mathrm{wt} \%, 320^{\circ} \mathrm{C}, 50 \mathrm{~kg} / \mathrm{cm}^{2}$, WHSV $14 \mathrm{~h}^{-1}, \mathrm{H}_{2} 18 \mathrm{l} / \mathrm{h}$, DBT 1 wt $\%$ in decalin. b) Values in parentheses show the ratio of labile sulfur to ruthenium. c) The value of $S_{\mathrm{t}}$ (total sulfur) assumes that ruthenium species are present as RuS 2 . d) Calculated from the conversions. e) $280^{\circ} \mathrm{C}$. f) $300^{\circ} \mathrm{C}$

catalysts. Radioisotope tracer methods using radioactive ${ }^{35} \mathrm{~S}$ have been developed to explore the behavior of sulfur species on the catalyst and are described elsewhere in detail ${ }^{1), 84) \sim 90)}$. The use of a ${ }^{35} \mathrm{~S}$ tracer such as ${ }^{35} \mathrm{~S}$-labeled $\mathrm{H}_{2} \mathrm{~S}, \mathrm{CS}_{2}$, or thiophene is believed to clarify the behavior of sulfur in catalysts. However, how the sulfur in catalysts is involved in the practical performance of HDS is unclear. Hydrodesulfurization of ${ }^{35} \mathrm{~S}$-labeled dibenzothiophene $\left(\left[{ }^{35} \mathrm{~S}\right] \mathrm{DBT}\right)$ over sulfided $\mathrm{Co}-\mathrm{Mo} / \mathrm{Al}_{2} \mathrm{O}_{3}, \mathrm{Ni}-\mathrm{Mo} / \mathrm{Al}_{2} \mathrm{O}_{3}, \mathrm{Mo} / \mathrm{Al}_{2} \mathrm{O}_{3}, \mathrm{Co} / \mathrm{Al}_{2} \mathrm{O}_{3}$ and $\mathrm{Ni} / \mathrm{Al}_{2} \mathrm{O}_{3}$ catalysts has provided new insight into the mechanism of HDS by monitoring the changes in the radioactivities of the unreacted $\left[{ }^{35} \mathrm{~S}\right] \mathrm{DBT}$ and the formed $\left[{ }^{35} \mathrm{~S}_{3} \mathrm{H}_{2} \mathrm{~S}^{91) ~ 98)}\right.$. The sulfur of DBT is not directly released as hydrogen sulfide but is initially accommodated on the catalyst and is not removed without the incorporation of sulfur from the HDS of sulfur compounds. Quantitative analysis of the rate of $\left.{ }^{35} \mathrm{~S}\right] \mathrm{H}_{2} \mathrm{~S}$ formation from the catalyst suggests that the sulfur on the sulfided catalyst is labile and the amount of labile sulfur on the catalyst varies with the reaction conditions. This radioactive tracer method has provided a more exact understanding of how sulfur in DBT is translated to $\mathrm{H}_{2} \mathrm{~S}$ and how sulfur in the sulfided catalyst participates in the actual HDS reaction.

HDS of $\left.{ }^{35} \mathrm{~S}\right] \mathrm{DBT}$ was performed on ruthenium catalysts with presulfiding of $\mathrm{Ru}_{3}(\mathrm{CO})_{12}-n \mathrm{CsOH} / \mathrm{Al}_{2} \mathrm{O}_{3}$ systems $(n=0,3,6 \text { or } 9)^{99), 100)}$. Figure 13 shows the changes in the radioactivities of unreacted $\left.{ }^{35} \mathrm{~S}\right] \mathrm{DBT}$ and formed $\left[{ }^{35} \mathrm{~S}_{3} \mathrm{H}_{2} \mathrm{~S}\right.$, and the conversion of DBT with reaction time at $280^{\circ} \mathrm{C}$ using the $\mathrm{Ru}_{3}(\mathrm{CO})_{12}-6 \mathrm{CsOH} /$ $\mathrm{Al}_{2} \mathrm{O}_{3}$ system. After the conversion of $\left.{ }^{32} \mathrm{~S}\right] \mathrm{DBT}$ by HDS reached a constant value and the solution of $\left[{ }^{32} \mathrm{~S}\right] \mathrm{DBT}$ was replaced by that of $\left[{ }^{35} \mathrm{~S}\right] \mathrm{DBT}$, the radioactivities of unreacted $\left.{ }^{35} \mathrm{~S}\right] \mathrm{DBT}$ in liquid products increased with reaction time and reached a steady state immediately. In contrast, the time delay in the case of ${ }^{35} \mathrm{~S}_{3} \mathrm{H}_{2} \mathrm{~S}$ was about $6 \mathrm{~h}$. A decalin solution of $\left[{ }^{32} \mathrm{~S}\right] \mathrm{DBT}$ was substituted for $\left.{ }^{35} \mathrm{~S}\right] \mathrm{DBT}$ in a similar way. The time delay for the decrease of the radioactivity of unreacted $\left[{ }^{35} \mathrm{~S}\right] \mathrm{DBT}$ from the steady state to the normal state was $30 \mathrm{~min}$ whereas that for the $\left[{ }^{35} \mathrm{~S}_{3} \mathrm{H}_{2} \mathrm{~S}\right.$ was about $6 \mathrm{~h}$. This result indicates that the sulfur in DBT is not directly released as hydrogen sulfide but is accommodated on the catalyst, and is consistent with the result from $\mathrm{Al}_{2} \mathrm{O}_{3}$-supported molybdenum catalysts $^{\text {91) }}$ 95).

Data for the catalyst derived from the $\mathrm{Ru}_{3}(\mathrm{CO})_{12-}$ $6 \mathrm{CsOH} / \mathrm{Al}_{2} \mathrm{O}_{3}$ system were treated as follows: The first order plot of the decreasing radioactivity of $\left[{ }^{35} \mathrm{~S}\right] \mathrm{H}_{2} \mathrm{~S}$ in Fig. 13 indicates a linear relationship given by

$$
\ln y=\ln z-k t
$$

where $y$ represents the radioactivity of $\left[{ }^{35} \mathrm{~S}\right] \mathrm{H}_{2} \mathrm{~S}(\mathrm{dpm} /$ $\min ) ; z$ the radioactivity of $\left[{ }^{35} \mathrm{~S} \mathrm{H}_{2} \mathrm{~S}\right.$ at steady state $(\mathrm{dpm} / \mathrm{min}) ; k$ the rate constant of the release of $\left[{ }^{35} \mathrm{~S}\right] \mathrm{H}_{2} \mathrm{~S}$ $\left(\mathrm{min}^{-1}\right) ; t$ reaction time (min). The value of $k$ indicates the relative ease of migration of sulfur on the catalyst ${ }^{91) ~ 95)}$. The amount of labile sulfur on the catalyst $\left(S_{\mathrm{o}}\right)$, which may represent the amount of the active sites, can be caluculated from the total radioactivity of the released $\left.{ }^{[35} \mathrm{S}\right] \mathrm{H}_{2} \mathrm{~S}$ (area B) ${ }^{91)}-95$ ).

The values of $k$ and $S_{\mathrm{o}}$ for these catalysts were estimated by similar methods as described above using these data and are shown in Table 3. As described in the previous sections ${ }^{79), 80), 82), 83)}$, the conversion of DBT increased with the amount of cesium added and reached the maximum at $\mathrm{Ru}: \mathrm{Cs}=1: 2$, whereas further addition of cesium decreased the conversion. The values of $S_{\mathrm{o}}$ for the catalysts increased with the amount of cesium added and reached the maximum at $\mathrm{Ru}: \mathrm{Cs}=$ $1: 2$, which was maintained with further addition of cesium ( $\mathrm{Ru}: \mathrm{Cs}=1: 3$ ). This result shows that the active sites on the catalyst were not poisoned because $S_{\mathrm{o}}$ did not decrease with addition of excess cesium. This maximum value of $S_{\mathrm{o}}$ at $\mathrm{Ru}: \mathrm{Cs}=1: 2$ corresponds to $\mathrm{RuS}_{1.52}$. Assuming that all ruthenium species is present as $\mathrm{RuS}_{2}, 76 \%$ of the sulfur on the catalyst is labile. This result shows that the dispersion of the ruthenium species could be significantly high. The rate constant of $\left[{ }^{35} \mathrm{~S}\right] \mathrm{H}_{2} \mathrm{~S}$ release $(k)$ decreased with addition of cesium, indicating that the mobility of sulfur on the catalysts was decreased by more cesium. 
These results suggest that cesium strengthens the $\mathrm{Ru}-\mathrm{S}$ bonds of ruthenium sulfide. As a result, the $\mathrm{C}-\mathrm{S}$ bond scission of DBT was promoted and the activity was increased. However, the $\mathrm{Ru}-\mathrm{S}$ bonds became too strong with the addition of excess cesium. The formation of $\mathrm{H}_{2} \mathrm{~S}$ and the regeneration of the coordinatively unsaturated sites were prevented, which resulted in decreased activity. Also, there is an optimum $\mathrm{Ru}-\mathrm{S}$ bond strength to obtain the highest catalytic activity ${ }^{101)}$.

As shown in Table 3, the values of $S_{o}$ for $\mathrm{Ru}-\mathrm{Cs}$ catalysts approximately corresponds to $\mathrm{RuS}_{0.36-1.55}$. Such amounts of labile sulfur are much higher than for the $\mathrm{Pt}$ and $\mathrm{Pd}$ catalysts $\mathrm{PtS}_{0.25}\left(\mathrm{PdS}_{0.25}\right)$ reported recent$\mathrm{ly}^{102), 103)}$. This result suggests that an oxidation state of the ruthenium species is present between the oxidation states of Pt or Pd and Mo and can change in a wide range during the HDS reaction, in contrast to $\mathrm{PtS}_{0.25}$ $\left(\mathrm{PdS}_{0.25}\right)$ and $\mathrm{MoS}_{2}$ which are unchanged under the usual HDS conditions. The recent process of HDS by $\mathrm{Ru}-\mathrm{Cs}$ catalysts using $\left[{ }^{35} \mathrm{~S}\right] \mathrm{H}_{2} \mathrm{~S}$ found that the labile sulfur was little formed during the presulfiding procedure but was formed only during the actual HDS ${ }^{104}$. Further, all sulfur on metal sulfide formed on the $\mathrm{Ru}-\mathrm{Cs}$ catalysts during HDS was labile sulfur. This characteristic of the ruthenium species would be closer to those of the Pt and Pd species than that of the Mo species because the ratio of labile sulfur in $\mathrm{MoS}_{2}$ formed during $\mathrm{HDS}$ was only approximately $59 \%$ at maximum for $\mathrm{Co}-\mathrm{Mo} / \mathrm{Al}_{2} \mathrm{O}_{3}{ }^{95}$.

\section{Conclusions}

Catalysts derived from supported anionic molybdenum and ruthenium carbonyl complexes are highly active and can be used for HDS of DBT. The supported anionic molybdenum complex with metal-sulfur bonds $\left(\mathrm{Mo}(\mathrm{CO})_{6}-\mathrm{NEt}_{3}-\mathrm{EtSH} / \mathrm{Al}_{2} \mathrm{O}_{3}\right.$ system) activated by $\mathrm{H}_{2}$ or $\mathrm{H}_{2} \mathrm{~S}$, has the highest catalytic activity among catalysts derived from supported-metal carbonyls and conventional molybdena-alumina. $\mathrm{SiO}_{2}-\mathrm{Al}_{2} \mathrm{O}_{3}$ was the most effective support for anionic molybdenum carbonyl complexes.

Addition of alkali metals, especially Cs, to the alumina-supported ruthenium carbonyl system remarkably increased the conversion of DBT and selectively produced BP in HDS of DBT. The formation of an anionic ruthenium hydride complex $\left[\mathrm{HRu}_{3}(\mathrm{CO})_{11}\right]^{-}$during the preparation of the catalyst is essential to obtain the high catalytic activity.

The involvement of cesium in HDS of $\left[{ }^{35} \mathrm{~S}\right] \mathrm{DBT}$ on $\mathrm{Ru}-\mathrm{Cs}$ catalysts was elucidated by tracing the behavior of ${ }^{35} \mathrm{~S}$ on the working ruthenium catalysts. Cesium apparently promotes the $\mathrm{C}-\mathrm{S}$ bond scission of DBT and increases the activity by stabilizing the $\mathrm{Ru}-\mathrm{S}$ bonds of ruthenium sulfide.

\section{Acknowledgment}

A part of this work was carried out as a research project of The Japan Petroleum Institute commissioned by the Petroleum Energy Center with a subsidy from The Ministry of International Trade and Industry, Japan.

\section{References}

1) Kabe, T., Ishihara, A., Qian, W., "Hydrodesulfurization and Hydrodenitrogenation," Kodansha Scientific, Wiley-VCH, Tokyo, New York, Berlin, (1999).

2) Topsøe, H., Clausen, B. S., Massoth, E. E., "Hydrotreating Catalysis," Springer, Berlin, New York, Tokyo, (1996).

3) Stiefel, E. I., Pan, W.-H., Chianelli, R. R., Ho, T. C., U.S. Pat. 4 581125 (1986).

4) Stiefel, E. I., Halbert, T. R., Coyle, C. L., Wei, L., Pan, W.-H., Ho, T. C., Chianelli, R. R., Daage, M., Polyhedron, 8, 1625 (1989).

5) Eltzner, W., Breysse, M., Lacroix, M., Vrinat, M., Polyhedron, 5, 203 (1986).

6) Müller, A., Diemann, E., Branding, A., Baumann, F. W., Breysse, M., Vrinat, M., Appl. Catal., 62, L13 (1990).

7) Yermakov, Y. I., Catal. Rev.-Sci. Eng., 13, 77 (1976).

8) Bailey, D. C., Langer, S. H., Chem. Rev., 81, 109 (1981).

9) Phillips, J., Dumesic, J. A., Appl. Catal., 9, 1 (1984).

10) Howe, R. F., "Tailored Metal Catalysts," ed. by Iwasawa, Y., Reidel, Dordrecht (1986), p.141.

11) Ichikawa, M., "Tailored Metal Catalysts," ed. by Iwasawa, Y., Reidel, Dordrecht (1986), p.183.

12) Ishihara, A., Mitsudo, T., Watanabe, Y., Sekiyu Gakkaishi, 33, (1), 28 (1990) and literature cited therein.

13) Ishihara, A., Mitsudo, T., Morita, N., Watanabe, Y., Sekiyu Gakkaishi, 33, (5), 327 (1990).

14) Mitsudo, T., Ishihara, A., Watanabe, Y., Ind. Eng. Chem. Res., 29, 163 (1990).

15) Banks, R. L., Bailey, G. C., Ind. Eng. Chem., Prod. Res. Dev., 3, 170 (1964).

16) Banks, R. L., Chemtech, 112 (1986).

17) Brenner, A., Burwell Jr., R. L., J. Am. Chem. Soc., 97, 2565 (1975).

18) Goldwasser, J., Fang, S. M., Houalla, M., Hall, W. K., J. Catal., 115, 34 (1989).

19) Cid, R., Fierro, J. L. G., Lopez-Agudo, A., Zeolites, 10, 95 (1990).

20) Okamoto, Y., Odawara, M., Onimatsu, H., Imanaka, T., Ind. Eng. Chem. Res., 34, 3703 (1995).

21) Welters, W. J. J., Vorbeck, G., Zandbergen, H. W., de Haan, J. W., de Beer, V. H. J., van Santen, R. A., J. Catal., 150, 155 (1994).

22) Davidova, N., Kovacheva, P., Shopov, D., Zeolites, 6, 304 (1985).

23) Welters, W. J. J., de Beer, V. H. J., van Santen, R. A., Appl. Catal. A: Gen., 119, 253 (1994).

24) Laniecki, M., Zmierczak, W., Zeolite, 11, 18 (1991).

25) Sugioka, M., Takase, Y., Takahashi, K., Proc. of JECAT'91, 1991, p.224.

26) Curtis, M. D., Penner-Hahn, J. E., Schwank, J., Baralt, O., McCabe, D. J., Thompson, L., Waldo, G., Polyhedron, 7, 2411 (1988).

27) Brenner, J. R., Carvill, B. T., Thompson Jr., L. T., Appl. Organomet. Chem., 6, 463 (1992).

28) Carvill, B. T., Thompson, L. T., Appl. Catal., 75, 249 (1991).

29) Okamoto, Y., Katsuyama, H., AIChE J., 43, (11A), 2809 (1997).

30) Mauge, F., Vallet, A., Bachelier, J., Duchet, J. C., Lavalley, J. 
C., J. Catal., 162, 88 (1996).

31) Okamoto, Y., Imanaka, T., Sekiyu Gakkaishi, 36, (3), 182 (1993).

32) Halbert, T. R., Ho, T. C., Stiefel, E. I., Chianelli, R. R., Daage, M., J. Catal., 130, 116 (1991).

33) Ishihara, A., Azuma, M., Matsushita, M., Kabe, T., Sekiyu Gakkaishi, 36, (5), 360 (1993).

34) Ishihara, A., Nomura, M., Matsushita, M., Shirouchi, K., Kabe, T., "New Aspects of Spillover Effect in Catalysis," eds. by Inui, T. et al., Elsevier Science B. V., (1993), p.357.

35) Beck, B., Tadros, S., Z. Anorg. Allg. Chem., 375, 231 (1970).

36) Ruff, J. K., King, R. B., Inorg. Chem., 8, 180 (1969).

37) Maezawa, A., Kitamura, M., Okamoto, Y., Imanaka, T., Bull. Chem. Soc. Jpn., 61, 2295 (1988).

38) Ishihara, A., Shirouchi, K., Kabe, T., Chem. Lett., 589 (1993).

39) Ishihara, A., Shirouchi, K., Kabe, T., Sekiyu Gakkaishi, 37, (4), 411 (1994).

40) Doyle, G., J. Organonomet. Chem., 84, 323 (1975).

41) Kabe, T., Ishihara, A., Zhang, Q., Appl. Catal., A: Gen., 97, L1 (1993).

42) Ruff, J. K., King, R. B., Inorg. Chem., 8, 180 (1969).

43) Topsøe, N., Topsøe, H., J. Catal., 84, 386 (1983).

44) Clausen, B. S., Topsøe, H., Candia, R., Villadsen, J., Lengeler, B., Als-Nielsen, J., Christensen, F., J. Phys. Chem., 85, 3868 (1981).

45) Pecoraro, T. A., Chianelli, R. R., J. Catal., 67, 430 (1981).

46) Passaretti, J., Chianelli, R. R., Wold, A., Dwight, K., Covino, J., J. Solid State Chem., 64, 365 (1986).

47) Bellaloui, A., Mosoni, L., Roubin, M., Vrinat, M., Lacroix, M., Breysse, M., C. R. Acad. Sci. Paris, 304, 163 (1987).

48) De Los Reyes, J. A., Göbölös, S., Vrinat, M., Breysse, M., Catal. Lett., 5, 17 (1990).

49) Lacroix, M., Boutarfa, N., Guillard, C., Vrinat, M., Breysse, M., J. Catal., 120, 473 (1989).

50) Vrinat, M., Lacroix, M., Breysse, M., Mosoni, L., Roubin, M., Catal. Lett., 3, 405 (1989).

51) Oliver, S. W., Smith, T. D., Pilbrow, J., Harvey, T. G., Matheson, T. W., Pratt, K. C., Inorg. Chim. Acta, 117, L9 (1986).

52) Eijsbouts, S., de Beer, V. H. J., Prins, R., J. Catal., 109, 217 (1988).

53) Mitchell, P. C. H., Scott, C. E., Bonnelle, J. P., Grimblot, J. G., J. Catal., 107, 482 (1987).

54) Kuo, Y., Cocco, R. A., Tatarchuk, B. J., J. Catal., 112, 250 (1988).

55) Vissers, J. P. R., Groot, C. K., van Oers, E. M., de Beer, V. H. J., Prins, R., Bull. Soc. Chim. Belg., 93, 813 (1984).

56) Ledoux, M. J., Michaux, O., Agostini, G., Panissod, P., J. Catal., 102, 275 (1986).

57) Geantet, C., De Los Reyes, J. A., Vrinat, M., Breysse, M., Proceedings of JECAT'91, 1991, p.228.

58) De Los Reyes, J. A., Vrinat, M., Geantet, C., Breysse, M., Catal. Today, 10, (4), 645 (1991).

59) Geantet, C., Göbölös, S., De Los Reyes, J. A., Cattenot, M., Vrinat, M., Breysse, M., Catal. Today, 10, (4), 665 (1991).

60) Chary, K. V. R., Khajamasthan, S., Vijayakumar, V., J. Chem. Soc., Chem. Commun., 1339 (1989).

61) Göbölös, S., Lacroix, M., Decamp, T., Vrinat, M., Breysse, M., Bull. Soc. Chim. Belg., 100, 907 (1991).

62) Liaw, S.-J., Lin, R., Raje, A., Davis, B. H., Appl. Catal., A, 151, (2), 423 (1997).

63) Göbölös, S., Breysse, M., Cattenot, T., Decamp, M., Lacroix, M., Portefaix, J. L., Vrinat, M., "Advances in Hydrotreating Catalysts," eds. by Occelli, M. L., Anthony, R. G., Elsevier Science Publishers B. V., Amsterdam (1989), p. 243.

64) De Los Reyes, J. A., Vrinat, M., Appl. Catal. A: Gen., 103, 79 (1993).
65) Markel, E. J., Van Zee, J. W., J. Mol. Catal., 73, 335 (1992).

66) Harvey, T. G., Matheson, T. W., J. Chem. Soc., Chem. Commun., 188 (1985).

67) Harvey, T. G., Matheson, T. W., J. Catal., 101, 253 (1986).

68) Matheson, T. W., Pratt, K. C., Harvey, T. G., Int. Patent, BO1J29/12, CO1G 65/14, 27 March, 1986.

69) Spojakina, A., Damyanova, S., Shopov, D., Shokhireva, T., Yurieva, T., React. Kinet. Catal. Lett., 27, 333 (1985).

70) Poulet, O., Hubaut, R., Kasztelan, S., Grimblot, J., Bull. Soc. Chim. Belg., 100, 857 (1991).

71) Lopez Cordero, R., Lopez Guerra, S., Fierro, J. L. G., Lopez Agudo, A., J. Catal., 126, 8 (1990).

72) Sugioka, M., Sado, F., Matsumoto, Y., Maesaki, N., Catal. Today, 29, 255 (1996).

73) Sugioka, M., Tochiyama, C., Matsumoto, Y., Sado, F., Stud. Surf. Sci. Catal., 94, 544 (1995).

74) Sugioka, M., Andalaluna, L., Morishita, S., Kurosaka, T., Catal. Today, 39, (1-2), 61 (1997).

75) Vázquez, A., Pedraza, F., Fuentes, S., J. Mol. Catal., 75, 63 (1992).

76) Frety, R., Da Silva, P. N., Guenin, M., Appl. Catal., 57, 99 (1990).

77) Ishihara, A., Godo, H., Qian, W., Kabe, T. et al., Appl. Catal., A: Gen., 182, 345 (1999).

78) Ishihara, A., Matsushita, M., Shirouchi, K., Zhang, Q., Kabe, T., Sekiyu Gakkaishi, 39, (1), 26 (1996).

79) Ishihara, A., Nomura, M., Kabe, T., Chem. Lett., 2285 (1992).

80) Ishihara, A., Nomura, M., Takahama, N., Hamaguchi, K., Kabe, T., Sekiyu Gakkaishi, 39, (3), 211 (1996).

81) Johnson, B. F. G., Lewis, J., Raithby, P. R., Suess, G., J. Chem. Soc., Dalton Trans., 1356 (1979).

82) Ishihara, A., Nomura, M., Shirouchi, K., Kabe, T., Sekiyu Gakkaishi, 39, (6), 403 (1996).

83) Ishihara, A., Hamaguchi, K., Kabe, T., Sekiyu Gakkaishi, 40, (6), 516 (1997).

84) Lukens, H. R., Meisenheimer, J. R. G., Wilson, J. N., J. Phys. Chem., 66, 469 (1962).

85) Pavlova, K. A., Panteleea, B. D., Deryagina, E. N., Kalechits, I. V., Kinet. Katal., 6, (3), 493 (1965).

86) Kalechits, I. V., Deryagina, E. N., Kinet. Katal., 8, (3), 604 (1969).

87) Gachet, C. G., Dhainaut, E., de Mourgues, L., Candy, J. P., Fouilloux, P., Bull. Soc. Chim. Belg., 90, (12), 1279 (1981).

88) Isagulyants, G. V., Greish, A. A., Kogan, V. M., Symposium of International Catalyst Annual Conference in Canada, 1988, p.35.

89) Tetenyi, D. M., Zolton, P. P., Chem. Eng. Commun., 83, 1 (1989).

90) Gellman, A. J., Bussell, M. E., Somorjai, G. A., J. Catal., 107, 103 (1987).

91) Kabe, T., Qian, W., Ogawa, S., Ishihara, A., J. Catal., 143, 239 (1993).

92) Qian, W., Ishihara, A., Ogawa, S., Kabe, T., J. Phys. Chem., 98, (3), 907 (1994)

93) Kabe, T., Qian, W., Ishihara, A., J. Phys. Chem., 98, (3), 912 (1994).

94) Kabe, T., Qian, W., Ishihara, A., J. Catal., 149, 171 (1994).

95) Kabe, T., Qian, W., Wang, W., Ishihara, A., Catal. Today, 29, 197 (1996).

96) Qian, W., Zhang, Q., Okoshi, Y., Ishihara, A., Kabe, T., J. Chem. Soc., Faraday Trans., 93, (9), 1821 (1997).

97) Qian, W., Ishihara, A., Wang, G., Tsuzuki, T., Godo, M., Kabe, T., J. Catal., 170, 286 (1997).

98) Kabe, T., Qian, W., Tanihata, K., Ishihara, A., Godo, M., J. Chem. Soc., Faraday Trans., 93, (20), 3709 (1997).

99) Ishihara, A., Yamaguchi, M., Godo, H., Qian, W., Godo, M., Kabe, T., Chem. Lett., 743 (1996). 
100) Ishihara, A., Yamaguchi, M., Godo, H., Qian, W., Godo, M., Kabe, T., Sekiyu Gakkaishi, 41, (1), 51 (1998).

101) Chianelli, R. R., Catal. Rev.-Sci. Eng., 26, 361 (1984).

102) Kabe, T., Qian, W., Hirai, Y., Li, L., Ishihara, A., J. Catal.,
190, 191 (2000).

103) Qian, W., Yoda, Y., Hirai, Y., Ishihara, A., Kabe, T., Appl. Catal., A: Gen., 184, 81 (1999).

104) Unpublished result.

要 旨

\section{担持金属カルボニル錯体を用いたジベンゾチオフェンの水素化脱硫反応}

石原 篤, 銭 衛華, 加部 利明

東京農工大学工学部化学システム工学科, 184-8588 東京都小金井市中町 2-24-16

本論文では，アニオン性のモリブデンおよびルテニウムカル ボニル錯体を担体に担持して調製した触媒によるジベンゾチオ フェンの水素化脱硫反応を, 特に触媒活性と生成物選択性につ いて記述する。 $\mathrm{Mo}(\mathrm{CO})_{6}-\mathrm{NEt}_{3}-\mathrm{EtSH}_{2} / \mathrm{Al}_{2} \mathrm{O}_{3}$ 系の触媒を $\mathrm{H}_{2}$ ある いは $\mathrm{H}_{2} \mathrm{~S}$ で活性化した時，担持金属カルボニルより調製した 触媒や従来法で調製した触媒の中で最も高い触媒活性が得られ た。担体の効果を検討した結果, $\mathrm{SiO}_{2}-\mathrm{Al}_{2} \mathrm{O}_{3}>\mathrm{Al}_{2} \mathrm{O}_{3}>\mathrm{TiO}_{2}=$ Active carbon $>\mathrm{SiO}_{2}>\mathrm{NaY}$ zeolite $=\mathrm{HZSM}-5>\mathrm{HY}$ zeolite $の$ 順で 脱硫生成物の収率は低下した。

次に，アルミナ担持ルテニウムカルボニルを硫化して調製し た触媒を用いて DBTの水素化脱硫反応を行い,アルカリ金属 水酸化物添加の触媒活性および生成物選択性に及ほす効果を検 討した結果について述べる。アルミナ担持 $\mathrm{Ru}_{3}(\mathrm{CO})_{12}$ から得ら れる触媒にアルカリ金属水酸化物を加えるとDBTの転化率が 著しく増加した。 $\mathrm{Ru}_{3}(\mathrm{CO})_{12}$ とアルカリ金属水酸化物との反応 をあらかじめ行い, 生成したヒドリド錯体 $\left[\mathrm{HRu}_{3}(\mathrm{CO})_{11}\right]^{-を ア ~}$
ルミナに担持することが高い活性を得るために重要であった。 アルカリ金属の中では，Csが最も効果的であった。DBTの転 化率は $\mathrm{Cs} / \mathrm{Ru}=2$ で最大活性を示した。これ以上に $\mathrm{Cs}$ を添加 すると活性は低下した。この系では，ビフェニルが選択的に生 成した。

最後に, アルミナ担持ルテニウムカルボニルー水酸化セシウ 么系触媒を用いて ${ }^{35}$ S $]$ DBT の水素化脱硫反応を行い, 作動状 態のルテニウム触媒上における ${ }^{35} \mathrm{~S}$ の挙動を解析することによ りセシウムの役割を解明した結果について述べる。移動可能な 硫黄量は，触媒上に蓄積された ${ }^{35} \mathrm{~S} の$ 量より計算された。 $\left.{ }^{[3} \mathrm{S}\right] \mathrm{H}_{2} \mathrm{~S}$ 放出の速度定数は, 生成物である $\left[{ }^{35} \mathrm{~S}\right] \mathrm{H}_{2} \mathrm{~S}$ の放射能の 隇少過程の一次プロットより計算された。得られた結果はルテ ニウム種の分散度が高い可能性を示した。さらにセシウムは, ルテニウム硫化物の Ru-S 結合を安定化させることによって， DBT の C-S 結合の切断を促進し，活性を向上させていること が示唆された。

\section{Keywords}

Hydrodesulfurization, Dibenzothiophene, Anionic molybdenum carbonyls, Anionic ruthenium carbonyls, Cesium, Radioisotope 